
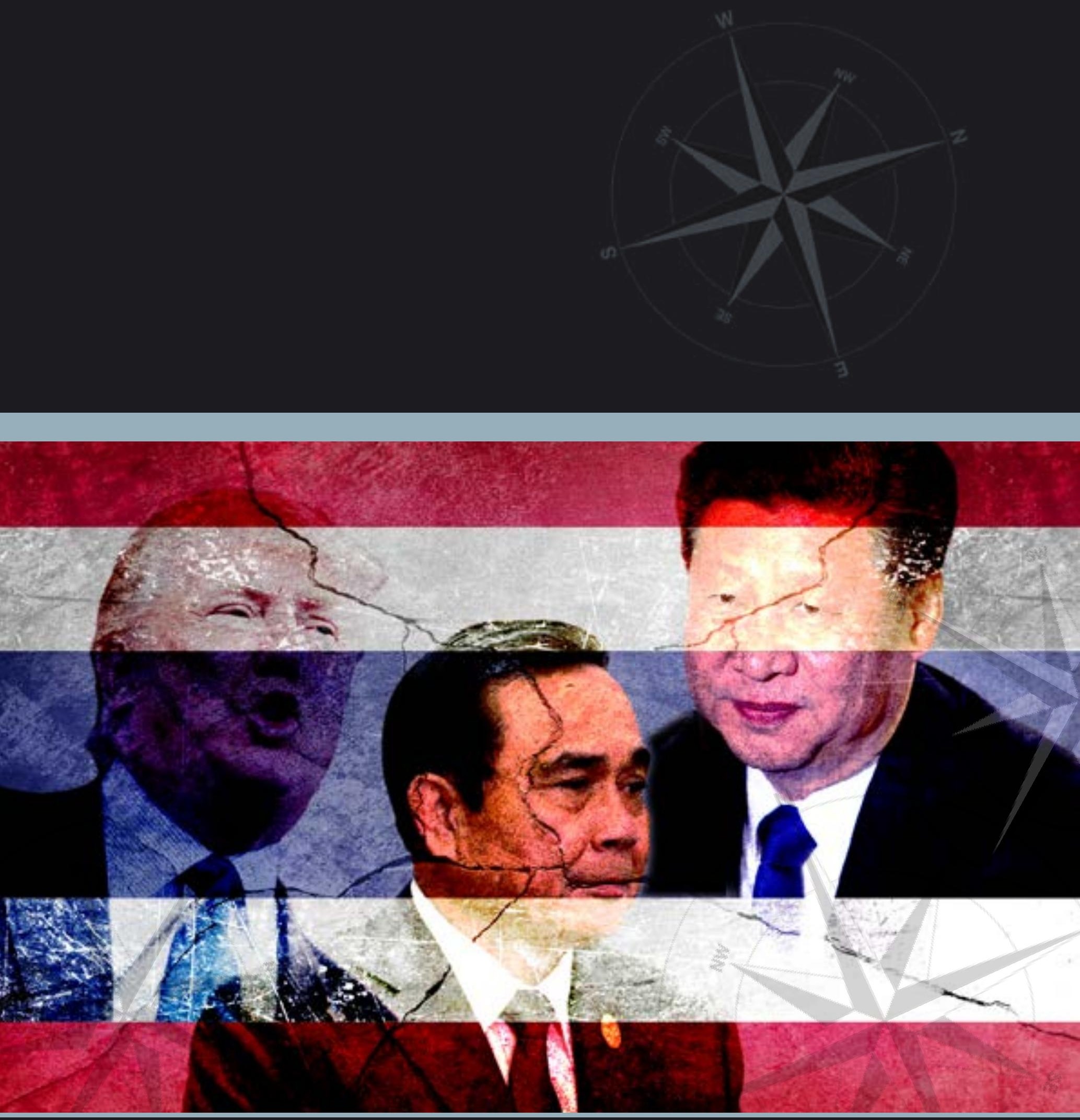


\section{The Centre of Gravity series}

\section{About the Centre of Gravity Series}

The Centre of Gravity Series is the flagship publication of the Strategic and Defence Studies Centre (SDSC) based at The Australian National University's College of Asia and the Pacific. The series aspires to provide high quality analysis and to generate debate on strategic policy issues of direct relevance to Australia. Centre of Gravity papers are 3,000-4,000 words in length and are written for a policy audience. Consistent with this, each Centre of Gravity paper includes at least one policy recommendation. Papers are commissioned by SDSC and appearance in the series is by invitation only. SDSC commissions up to 10 papers in any given year.

\section{About the Editor}

The Centre of Gravity Series is edited by Dr Andrew Carr, Senior Lecturer at the Strategic \& Defence Studies Centre. He has published widely on Australian strategic and defence policy, Asia-Pacific Security and Middle Powers. The COG series was developed to improve the conversation and engagement between academic and policy communities and draw attention to the most significant strategic questions facing Australia and the Asia-Pacific. Any comments or suggestions about how to improve the series or topics of particular interest are warmly welcomed. Dr Carr can be contacted on:

(E) Andrew.Carr@anu.edu.au

(M) 0421728207
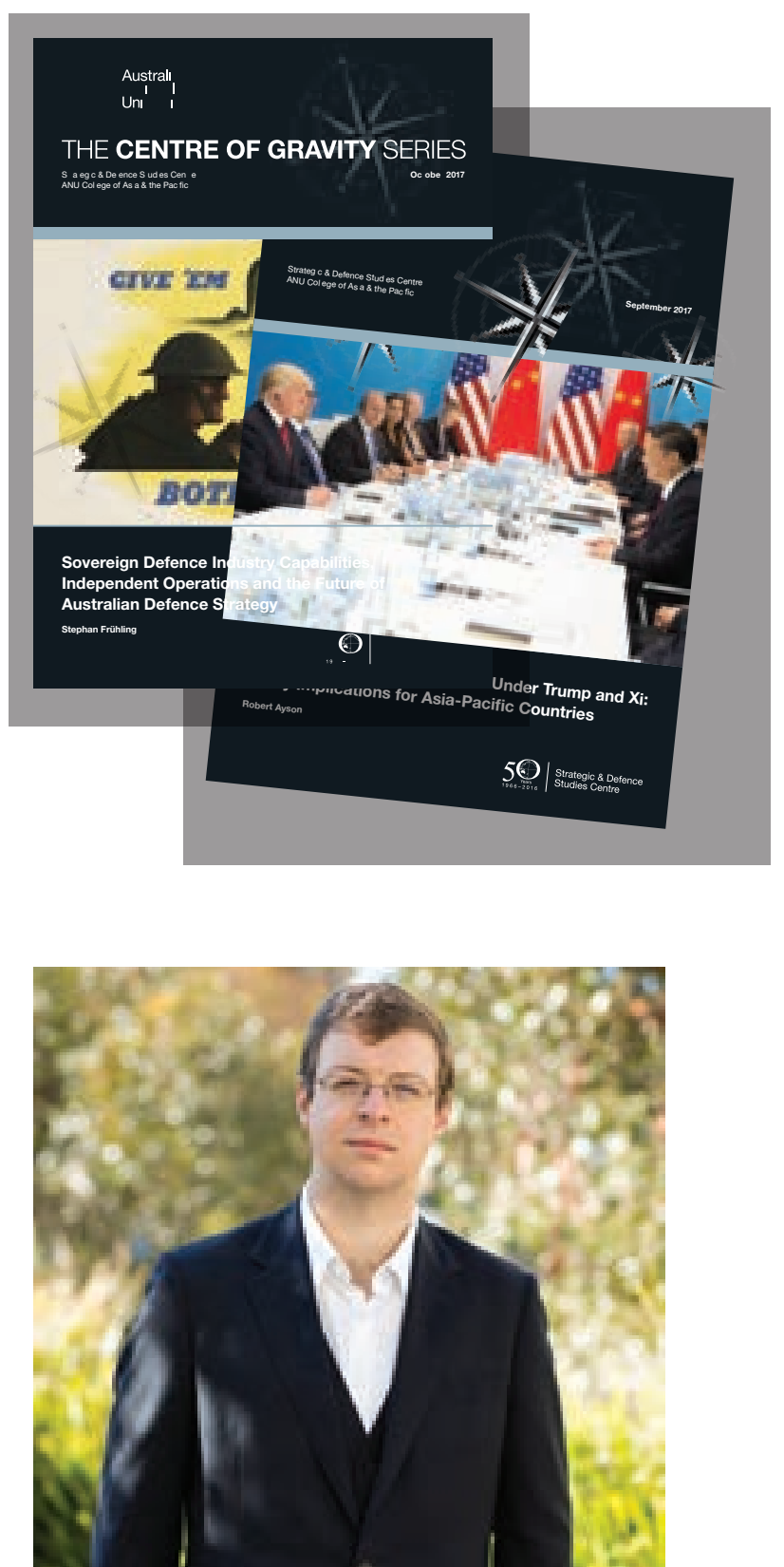

\section{Centre of Gravity series paper \#37}

Photos courtesy of Adobe Stock, Gage Skidmore via flickr.com, Foreign and Commonwealth Office via flickr.com, www.kremlin.ru, Staff Sgt. Teddy Wade via defense.gov, Shealah Craighead, Lance Cpl. Jeremy Laboy via Wikimedia Commons and Mass Communication Specialist 2nd Class Markus Castaneda via flickr.com

(C) 2017 ANU Strategic and Defence Studies Centre. All rights reserved.

The Australian National University does not take institutional positions on public policy issues; the views represented here are the author's own and do not necessarily reflect the views of the University, its staff, or its trustees.

No part of this publication may be reproduced or transmitted in any form or by any means without permission in writing from the ANU Strategic and Defence Studies Centre. Please direct inquiries to andrew.carr@anu.edu.au

This publication can be downloaded for free at sdsc.bellschool.anu.edu.au/our-publications/ centre-of-gravity-series

CRICOS\#00120C

ISSN: 2208-7311 (Online)

ISSN: 2208-7303 (Print) 


\title{
Tipping the Balance in Southeast Asia? Thailand, the United States and China
}

Foreword

John Blaxland and Greg Raymond's study breaks new ground in our understanding of Thai strategic and military culture and how Thai security elites view the United States, China, and the shifting geopolitical landscape in Asia. This analysis provides a roadmap to scholars seeking to understand shifting Thai policies and for policymakers seeking to maintain a strong footing for the U.S.-Thailand alliance during a time of strategic flux.

For centuries Thailand has been a master in the pursuit of strategic independence and balancing relations with great powers to avoid foreign domination. This tradition remains a powerful influence in Thai strategic culture, and it is thus perhaps unsurprising that Thai leaders have sought closer military and strategic ties with China. And yet at the same time, this preference for a balanced and independent foreign policy means that Thailand will not rush headlong into an embrace of China as a primary security partner. Rather, Thai security elites will seek to maintain the advantages brought by having a close security relationship with the United States.

A particularly valuable contribution of this Centre of Gravity study is what it reveals about the strategic advantages the United States continues to enjoy as a security partner to Thailand. The long, close relationship between the two militaries has created a large reserve of assets, relationships and positive experiences which are not easily replaced. These advantages include English language proficiency, adoption of U.S. military doctrine, and the volume and sophistication of joint military-to-military training and exercises.

This report is well timed, given the ongoing reassessment in Washington about the U.S.-Thailand alliance in the wake of the 2014 military coup. Unlike the previous coup in 2006, the 2014 coup was accompanied by harsh restrictions on civil liberties including freedom of speech and assembly, and it quickly became clear that a return to civilian rule and elections would be slow, and perhaps not fully democratic. This led the Obama administration to take a harder line on Thailand's military government than had been taken in response previous coups, including more vocal public criticism of the state of democracy and human rights in Thailand. Thai leaders deeply resented this treatment and relations began to cool considerably, with some noticeable effects on the alliance.

Efforts were underway at the end of the Obama administration to recalibrate its approach towards Thailand and reengage in some key areas, and these efforts towards normalizing relations have accelerated considerably under the Trump administration as it seeks to "revitalize" the U.S.-Thailand alliance. Prime Minister Prayuth Chan-o-cha met with President Trump at the White House in early October 2017, and was treated warmly as long-time friend and strategically important ally.

The United States has a strong interest in seeing Thailand return to a full-fledged stable democracy, and it also has a strong interest in the region resuming a more a positive trajectory towards democracy, human rights and good governance. The United States needs to be both principled and pragmatic in balancing these interests. The analysis and policy recommendations offered here by John Blaxland and Gregory Raymond will be indispensable for those seeking to find the right balance through skillful statecraft.

\author{
Amy Searight \\ Senior Adviser and Director, Southeast Asia Program \\ Centre for Strategic and International Studies \\ Washington D.C, USA
}




\section{About the authors}

John Blaxland is Professor of International Security and Intelligence Studies, Director ANU Southeast Asia Institute, and Head of the Strategic and Defence Studies Centre at ANU. He holds a PhD in War Studies from the Royal Military College of Canada, an MA in History from ANU, a BA (Hons 1) from UNSW and is a graduate of the Royal Thai Army Command and Staff College and the Royal Military College, Duntroon (Blamey Scholar). He has extensive experience in the intelligence community including as a former Director Joint Intelligence Operations (J2), at Headquarters Joint Operations Command. In addition he was Australia's Defence Attaché to Thailand and Burma/ Myanmar. His books include The Secret Cold War: The Official History of the Australian Security Intelligence Organisation 1975-1989 (Allen \& Unwin 2016), and East Timor Intervention (MUP, 2015).

Email: john.blaxland@anu.edu.au

Twitter: @JohnBlaxland1

Greg Raymond is a Research Fellow in the Strategic and Defence Studies Centre working on Southeast Asian security issues. Before joining the ANU, Greg worked extensively in the Australian Government, including in the strategic and international policy areas of the Department of Defence. His recent publications include 'Prospects for the Rules BasedGlobal Order' (ANU Centre of Gravity series, 2017) and 'Naval Modernization in Southeast Asia: Under the Shadow of Army Dominance?' published in Contemporary Southeast Asia, April 2017. His book on Thailand's strategic culture entitled Thai Military Power will be published in 2018 by NIAS Press. Greg also writes regularly for the Lowy Interpreter and East Asia Forum.

Email: greg.raymond@anu.edu.au Twitter: @GregoryVRaymond
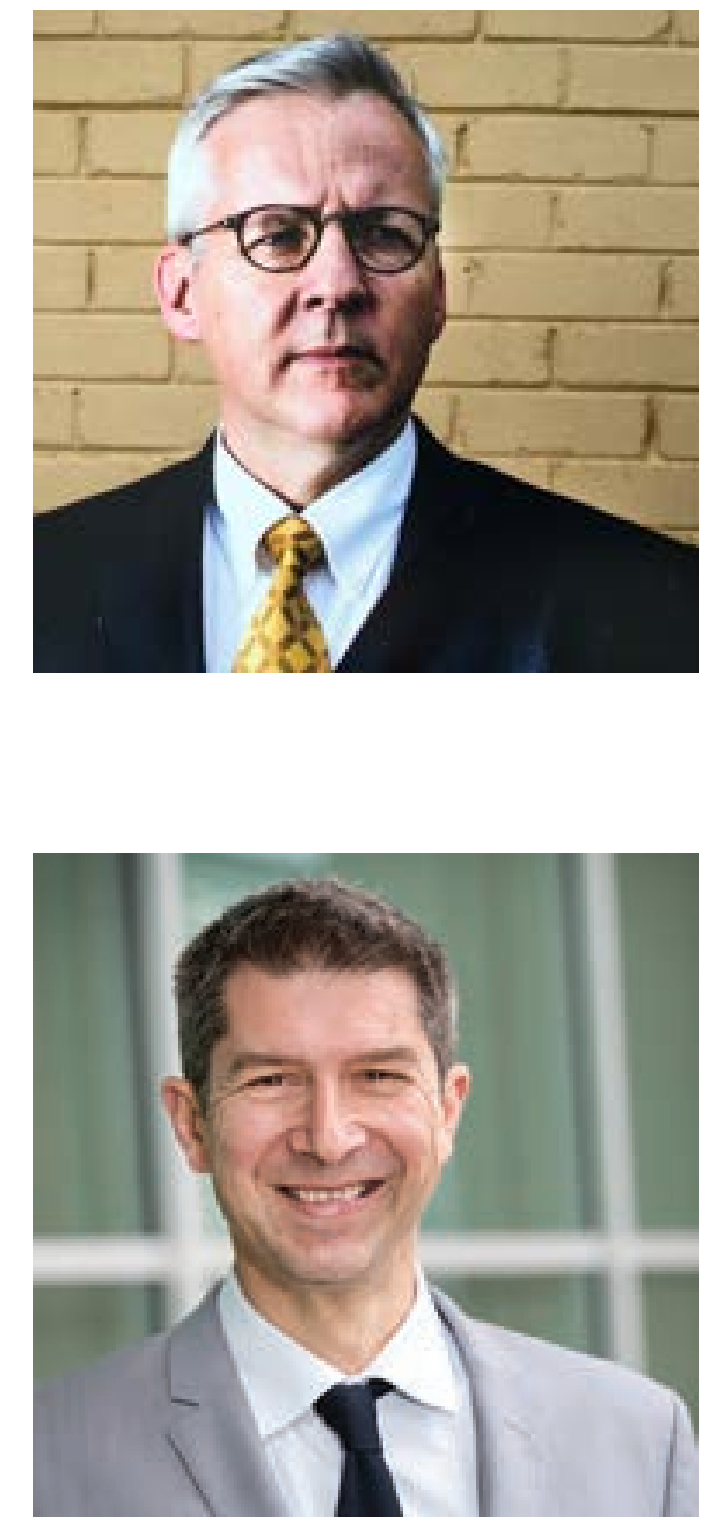

\section{Acknowledgements:}

This research was undertaken at the Australian National University and was funded by the Minerva research Initiative, through the Office of the Secretary of Defense. Special thanks to the support of those members of the Royal Thai Armed Forces and the King Prachadhipok Institute that made themselves available to participate in this project. 


\section{Tipping the Balance in Southeast Asia? Thailand, the United States and China}

John Blaxland and Greg Raymond

\section{Summary}

$\&$ This is a study of Thailand based on a survey of 1800 mainly military Thai officials.

$\&$ It shows China's influence has caught up and eclipsed that of the United States, with the tendency amplified by the Trump presidency and the perception of US political interference.

$\&$ The Thai military still places great store on the United States for security but for the present it is non-traditional security threats that are most keenly felt.

$\&$ Thai historical memory omits US protection and largesse during the Cold War, and downplays hostile Sino-Thai relations when China actively supported armed insurgents of the Communist Party of Thailand.

$\&$ Thailand has a tradition of great power balancing, so Thai-China military ties have understandably been growing, but Thailand also retains a strong preference for English language usage and American military doctrine and procedures.

$\&$ In addition, ASEAN is valued, being seen as a proto-great power, pivotal for Thailand's prosperity and security.

\section{Recommendations}

$\&$ Modulate approaches for advocating on democracy. Partner countries should continue to advocate for a return to democracy, but in a way that is less likely to be construed as interference or taking sides. The focus should be on representations in private meetings and a broad program of engagement on democratic processes and principles.

$\leftrightarrow$ Support more historical reflection. Historical scholarships and workshops should be provided on Cold War topics to encourage a more mature and balanced understanding of the period.

$\&$ Foster cultural and linguistic sensitivity. Partner countries should have closer engagement with messages conveyed in the Thai language.

\& Support ASEAN. Partner nations should demonstrate an awareness and support for ASEAN goals and programs.

$\&$ Avoid zero-sum views on Thailand and China. The Sino-Thai relationship is rich, long, deep and complex. But Thailand's own strategic culture is more influential on its national security choices.

$\&$ Engage on environmental challenges. Thailand and its neighbours have developed a keen interest in non-traditional security matters including massed migration, water shortages and over damming of the Mekong River. Support for countries like Thailand over emerging environmental challenges has the potential to generate considerable benefits. 


\section{Thailand's Window on Great Power dynamics in Southeast Asia}

Three years ago we began a research project funded by the US Department of Defense's Minerva Research Initiative entitled Thailand's Military, the USA and China: Understanding how the Thai Military Perceives the Great Powers and Implications for the US Rebalance. We wished to understand the kind of region we were heading towards. Where would the small states of Southeast Asia move geopolitically, as the broader region and indeed the globe experienced a historic shift of material power and economic weight to Asia?

In three years many significant events have occurred, some of which seem to accelerate the shift. China unveiled its intercontinental infrastructure investment vision, the Belt and Road Initiative. The United States withdrew from the Trans-Pacific Partnership trade agreement. China completed its building of three large airbases in the South China Sea and rejected an international court's judgement on maritime zones in the same vicinity. In this light, the question of how Southeast Asian states will navigate the emerging geopolitical landscape has become more important and interesting.

A case can be put that where goes Thailand so does the rest of Southeast Asia. ${ }^{1}$ Even if Thailand is a unique case, it is ASEAN's second largest economy, the largest economy in mainland Southeast Asia and occupies a pivotal position linking maritime and continental Southeast Asia. And it is, of course, a longstanding treaty ally of the United States.

We believe our study brings new depth, texture and certainty to the topic. Over the past three years we have surveyed over 1800 Thai military officers and officials, to find out how they view the Great Powers [see appendix for more details on who and how we surveyed].

Through our survey and interview questions we've sought to see how today's Thai officers and officials look back at Thailand's past dealings with the Great Powers. We believe that these past recollections are not determinative but are influential in shaping how Thai security elites see the Great Powers today, and their expectations about their future conduct and relations with Thailand. In this Centre of Gravity publication we explore the following issues:

- How Thailand's domestic politics have played into recent turbulence in the US-Thai alliance;

- How China turned from foe to friend in the final phase of the Cold War;

- The role of ethnicity, and whether Thailand's Sino-Thais shape attitudes towards China;

- Whether Thailand's recent procurement choices are a good guide to its foreign policy alignment; and

- American assets as China rises, including language and doctrinal commonalities, and Thailand's own strategic culture.

\section{Our respondents} saw the military threat from the United States as greater than any other Great Power, including China.

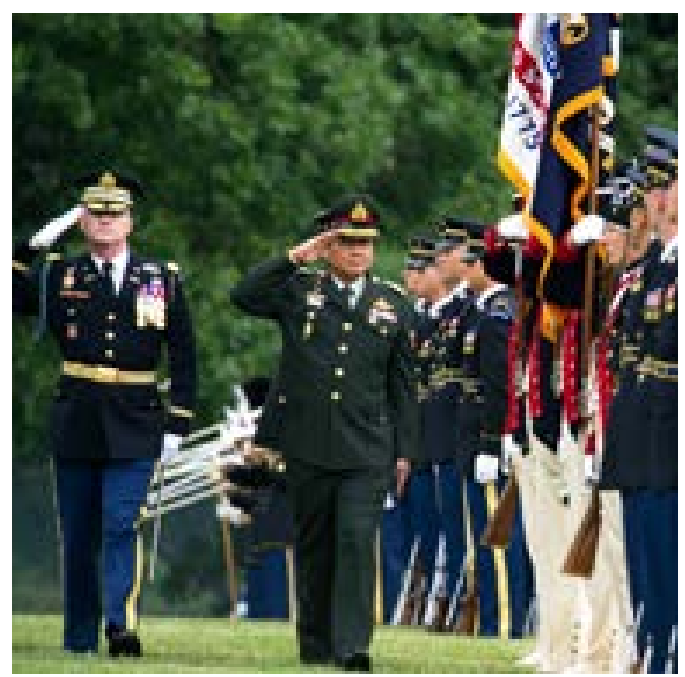

\section{The Changing Influence of the United States and China}

Thai military officers feel that the current era is one of historic transition. China's influence, they believe, has caught up with and passed that of the United States. When asked to rank influence (construed broadly) on a Likert scale from 1 (least influence) to 10, (maximum influence), the following median results were obtained for six different time periods extending from the nineteenth century to the present. 
FIGURE 1 Perceptions of China and United States influence from the nineteenth century to the present

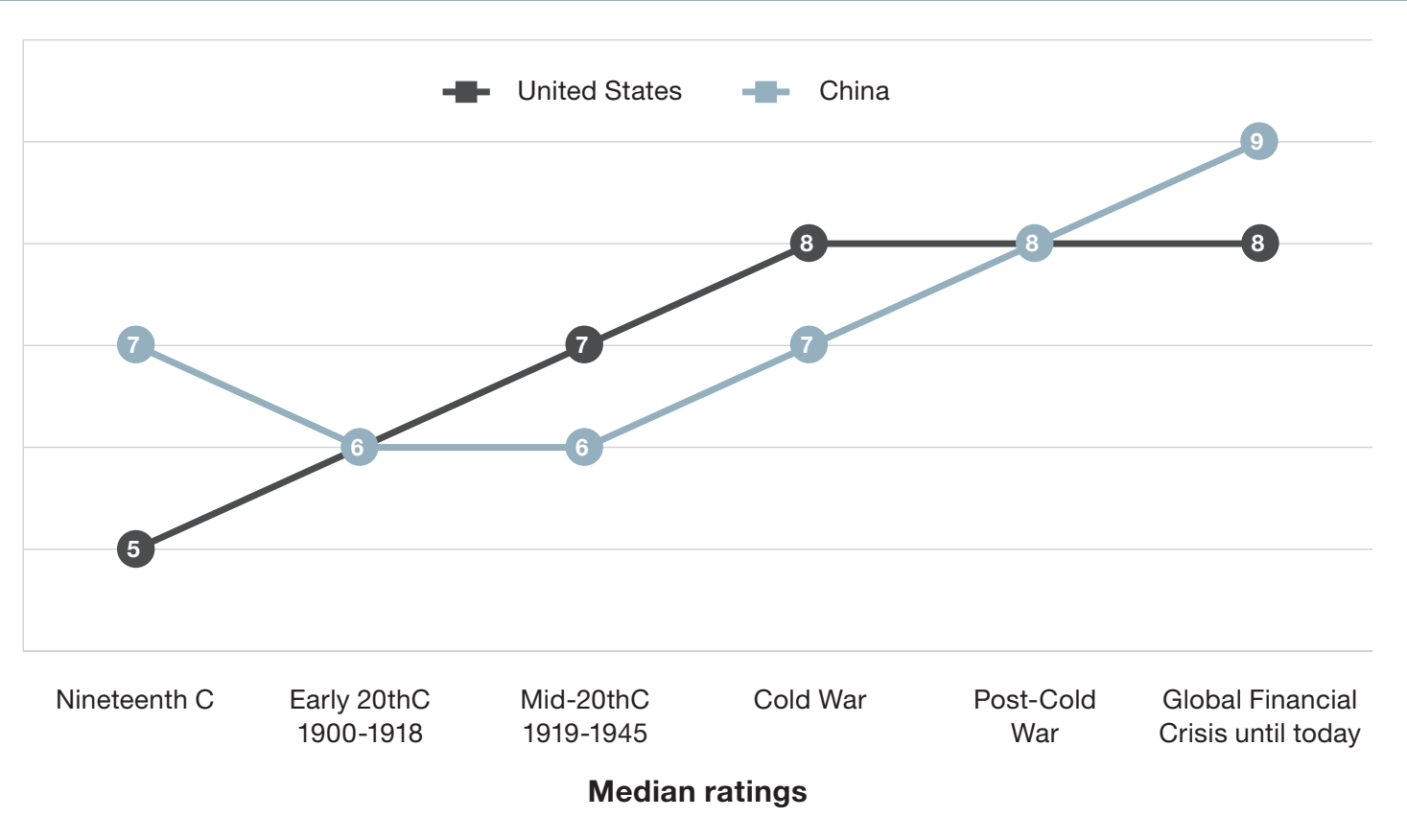

They expect China's influence to continue to grow in future, and to surpass the influence of the United States.

A similar overall pattern applies for how respondents see the significance of military support in influencing Thailand's national security policy, although here the US retains equal standing with China ( $1=$ not significant, $10=$ very significant).

FIGURE 2 Perceptions of China and United States influence on Thailand's national security policy from the nineteenth century to the present

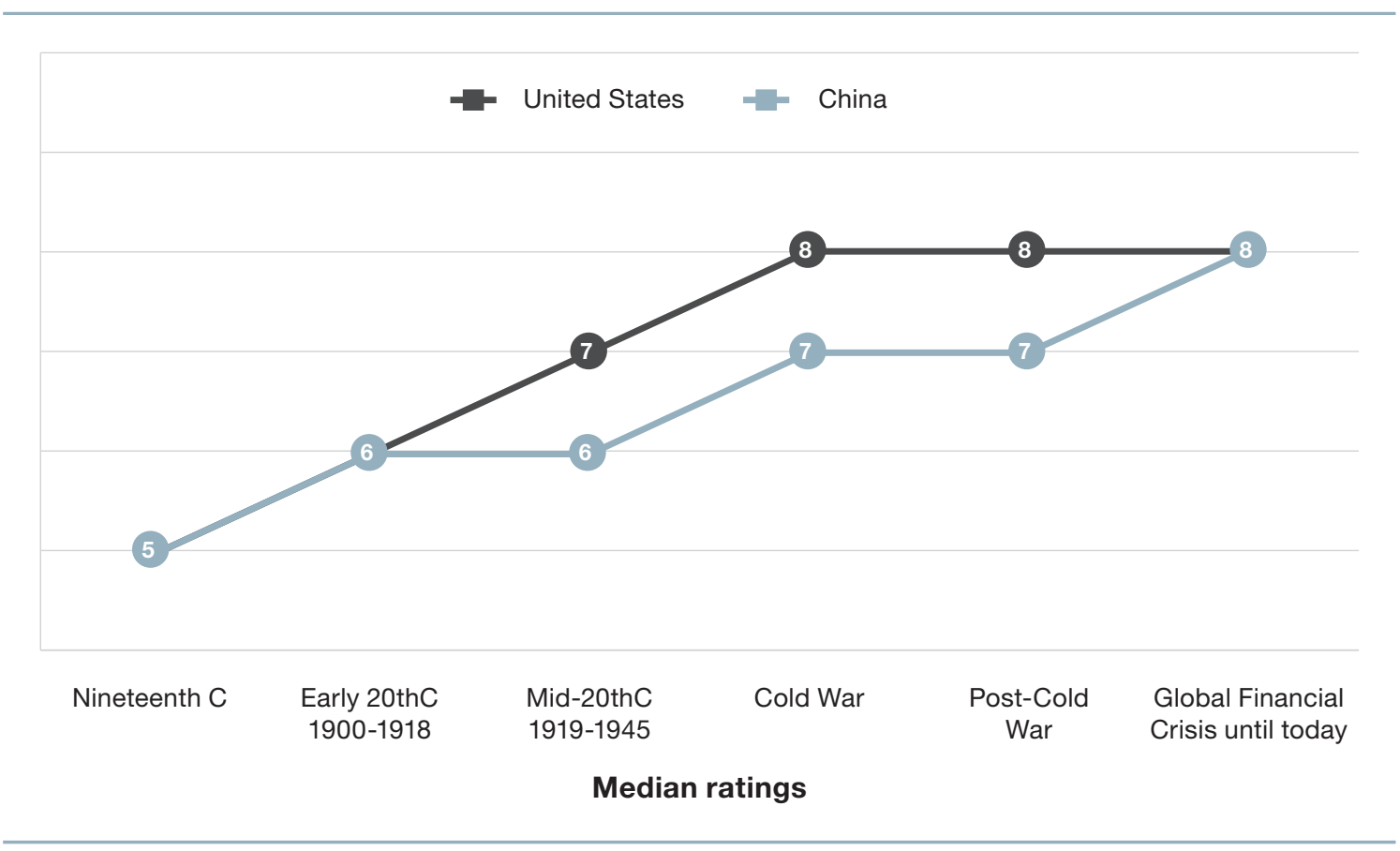


The election of the Trump administration is amplifying the tendency to see US influence waning compared to China in the next decade. Respondents in 2017 rated the United States influence in 10 years' time as lower than respondents in 2016.

\section{FIGURE 3 Expectations of United States future influence in 2016 and 2017 surveys.}

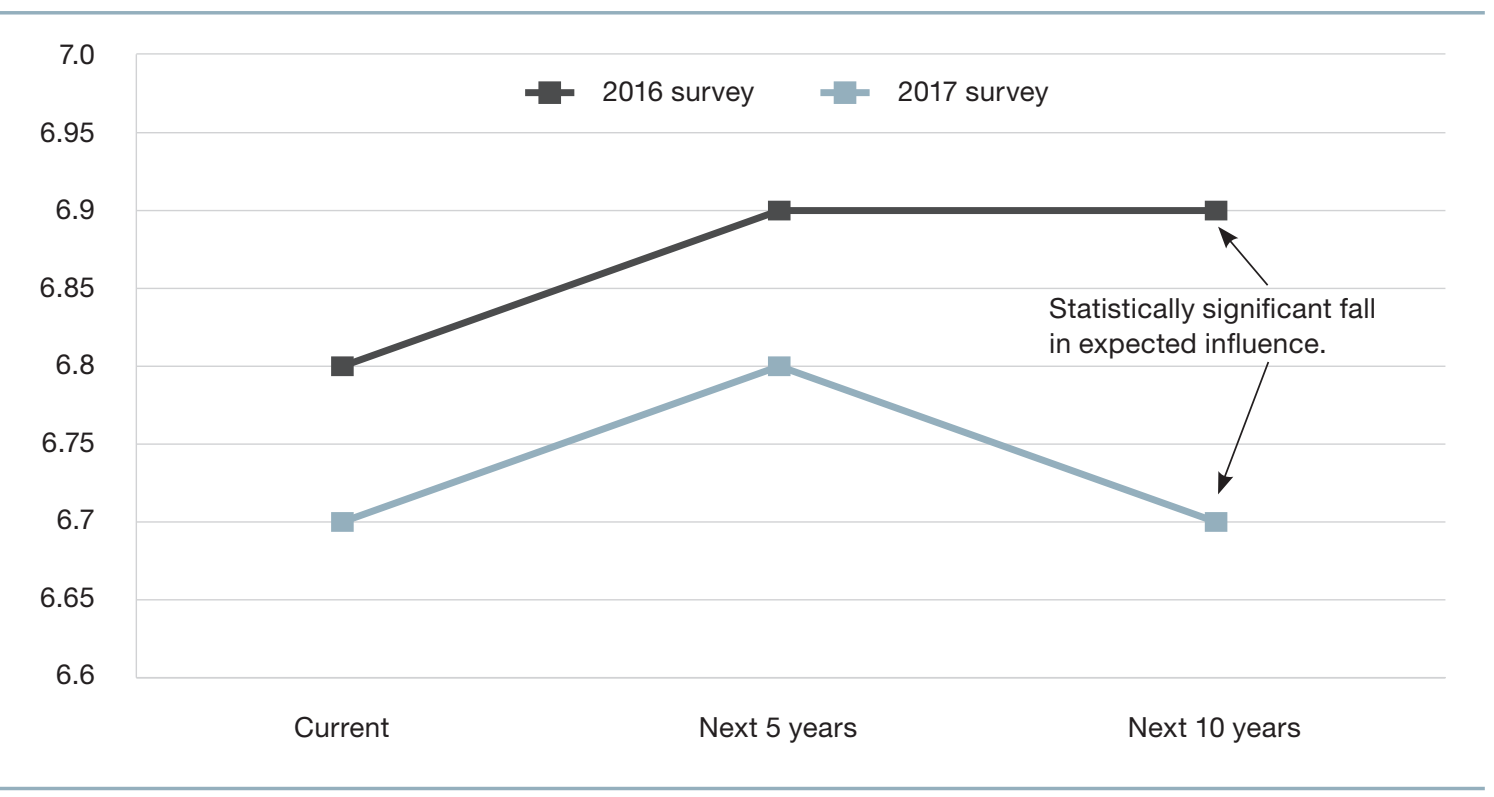

At the same time there is unease about China's growing power.

\section{FIGURE 4 Feelings about China's growing military power.}

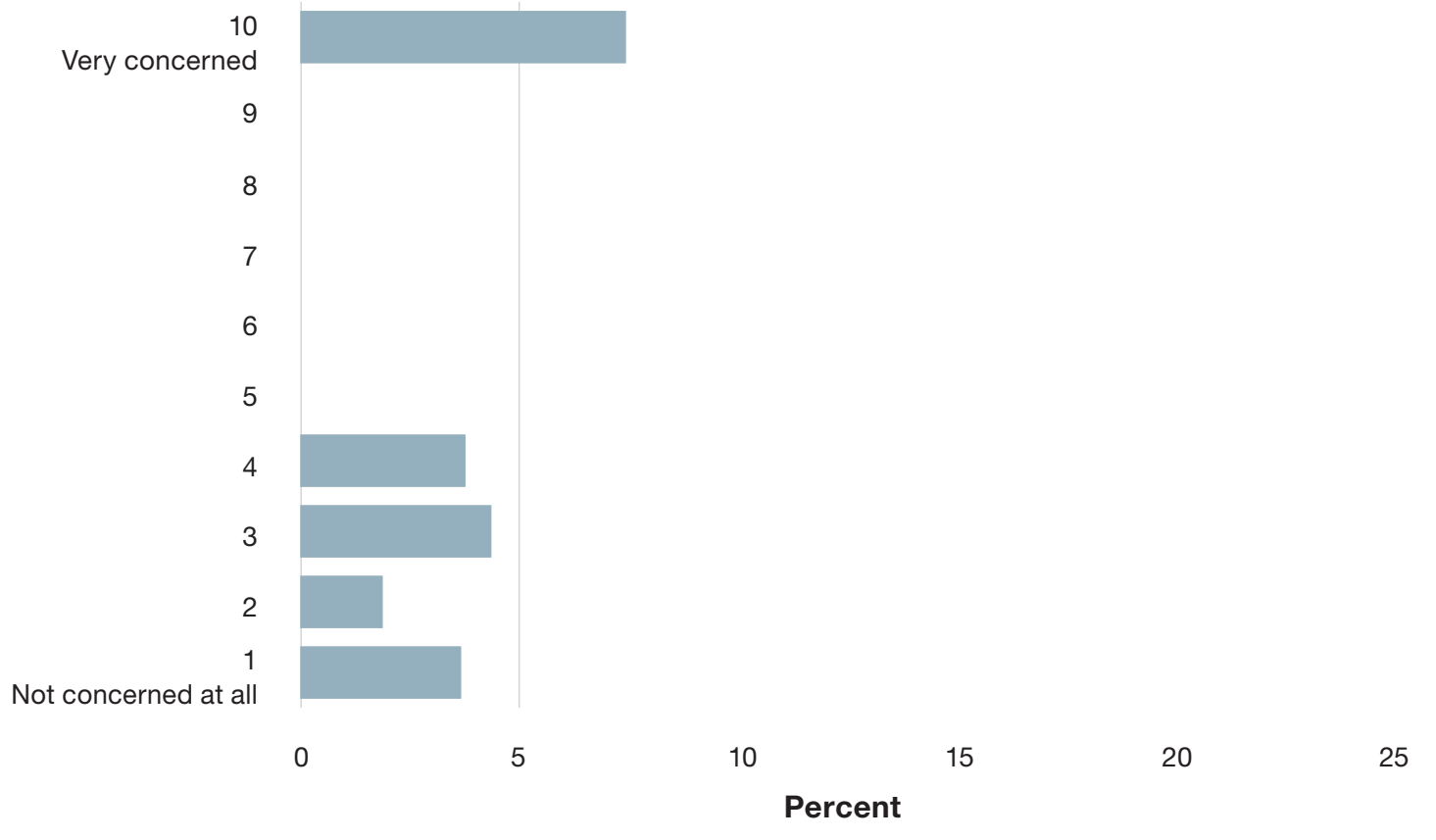

And there is also a curious puzzle - despite this unease about China's growing military capabilities, and a view that the US security guarantee is still important for Thailand, there is significant ambivalence to the United States. In fact in the present period, our respondents saw the military threat from the United States as greater than any other Great Power, including China. When asked how possible a military threat was from the following Great Powers, we obtained these Likert scale ratings, where 10 was very likely and 1 very unlikely: 


\section{FIGURE 5 Perceptions of threats from the Great Powers.}

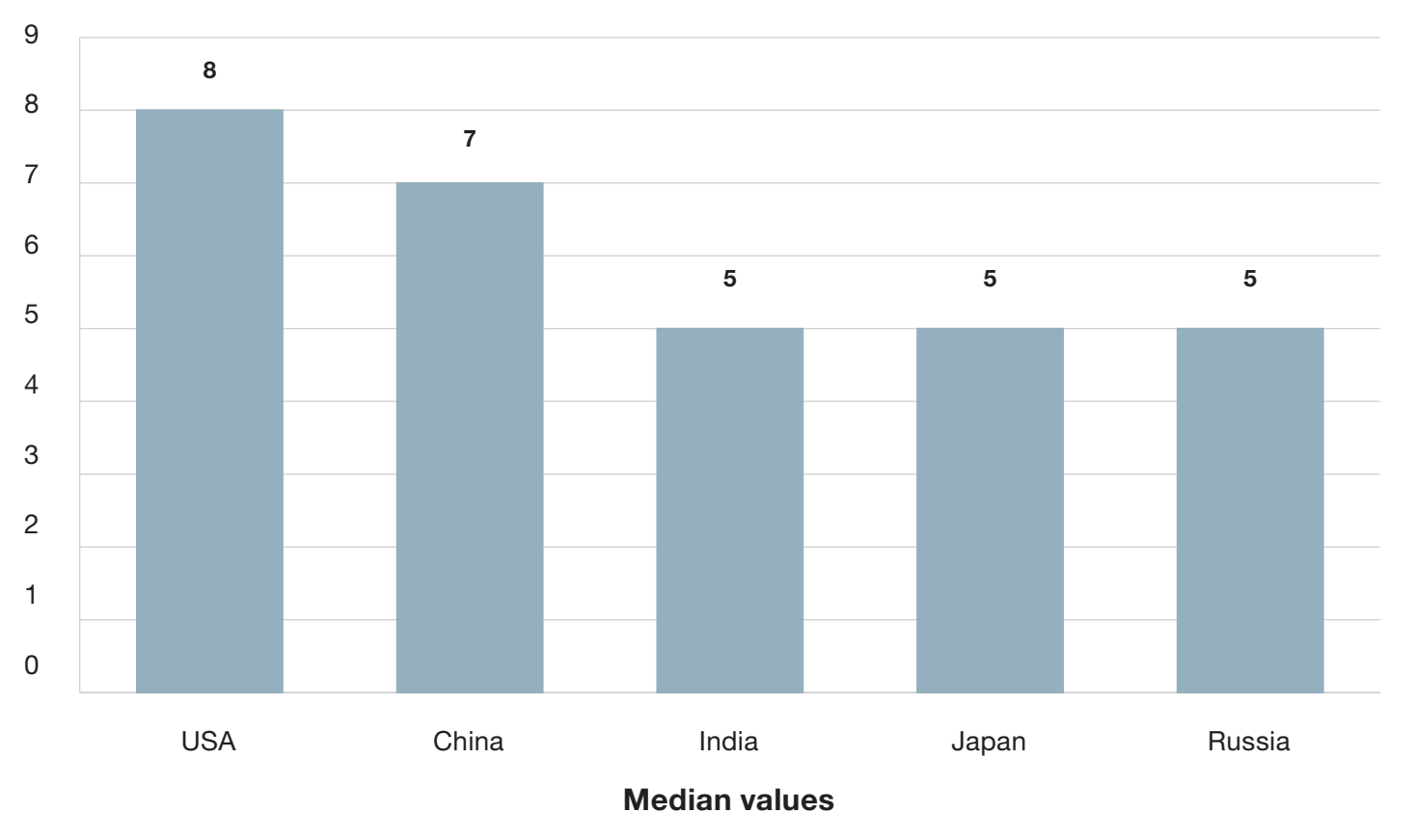

These results are striking, but we need to place these findings in context. In the following pages we drill down into these headline results, augmenting them with the voices of interviewees and supplementing them with exploration of several key issues.

\section{Thai Military Threat Perceptions}

A good place to begin is with Thailand's general security outlook. The survey evidence suggests that Thai military officers currently hold a benign view with regard to state-based military threats. Asked how secure they felt from external military threats, the median response was 7 .

\section{FIGURE 6 External military threat perceptions}

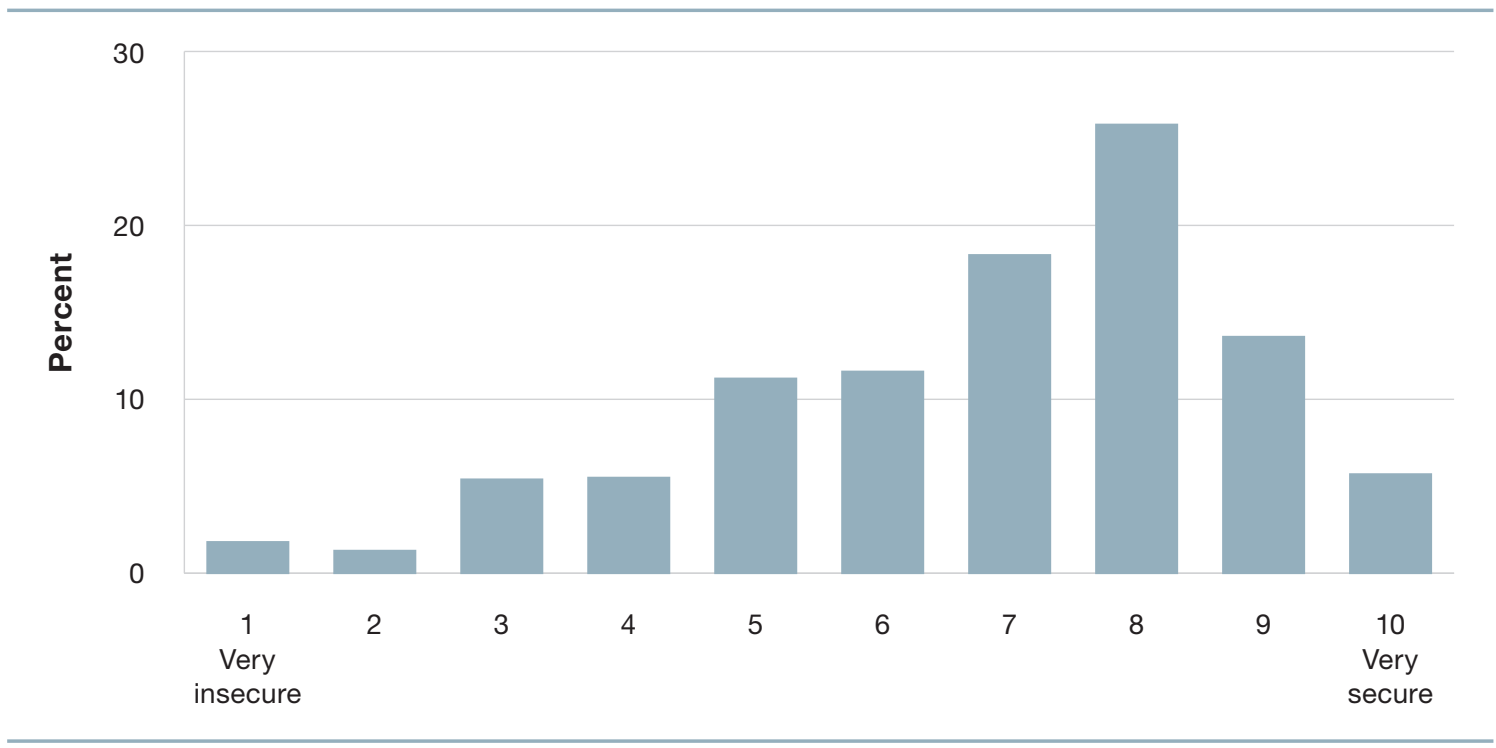

When asked to compare the significance of external threats from Great Powers, neighbouring countries and non-state threats, they saw threats from states as less significant than that of non-traditional threats such as transnational crime and pandemics. 


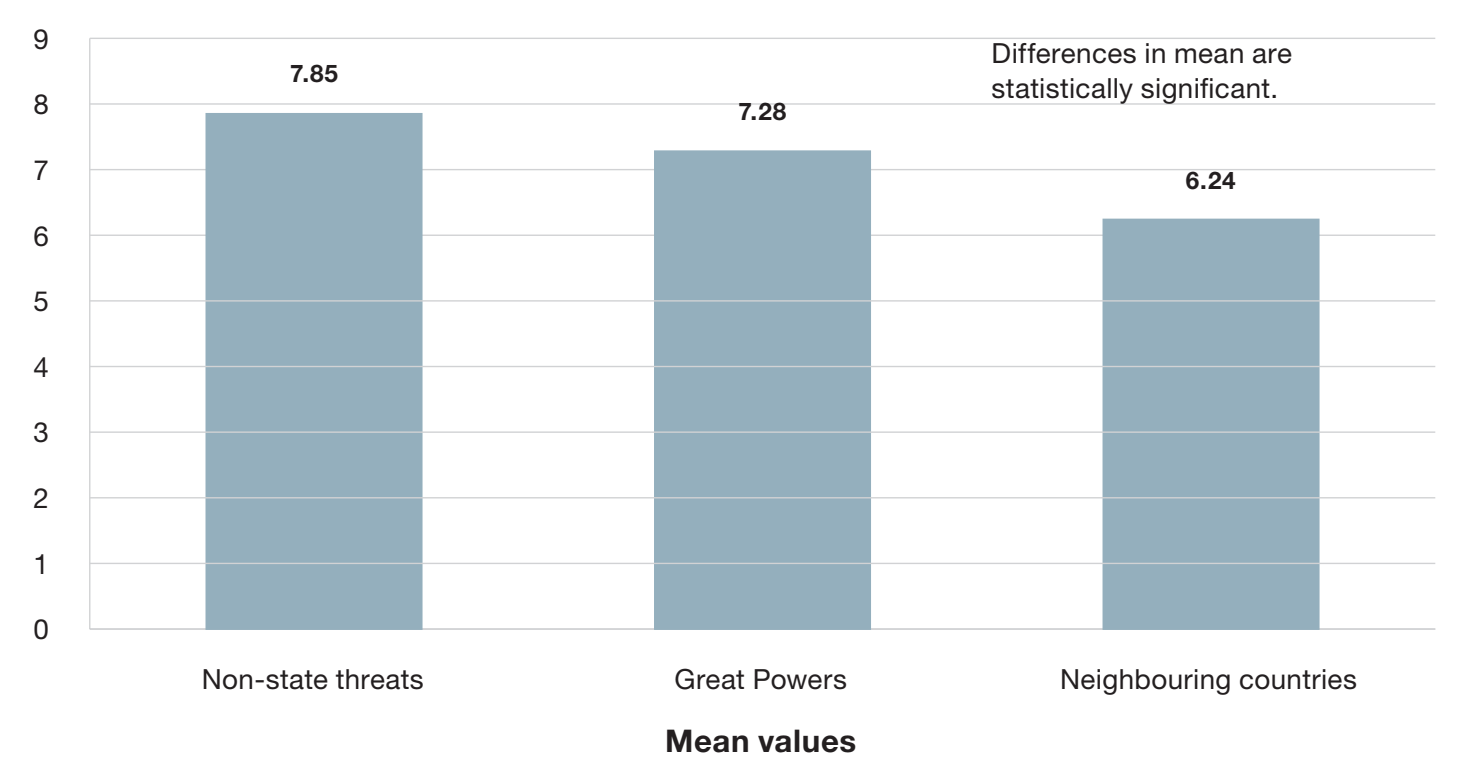

When we asked our interviewees about external military threats they could see no imminent threats. Instead the slow-burning conflict in Thailand's three southern border provinces, which in the past 13 years has claimed over 6000 lives, was a more tangible and immediate concern. But other nonstate threats also rated a mention. Climate change, it was noted, was now a more frequent topic of discussion. There were also concerns about globalisation, and the looser border controls introduced as part of the ASEAN Economic Community established in 2015. These might bring easier movement of drugs, illegal immigration and disease. Thai military officers generally don't view their neighbours as positively as countries such as Japan, Australia and South Korea, but neither do they see them as a source of threat. When asked 'How positively or negatively does Thailand view the following countries?' where 10 was 'very positively' and 1 was 'very negatively' the following responses were obtained:

\section{FIGURE 8 Views of other countries.}

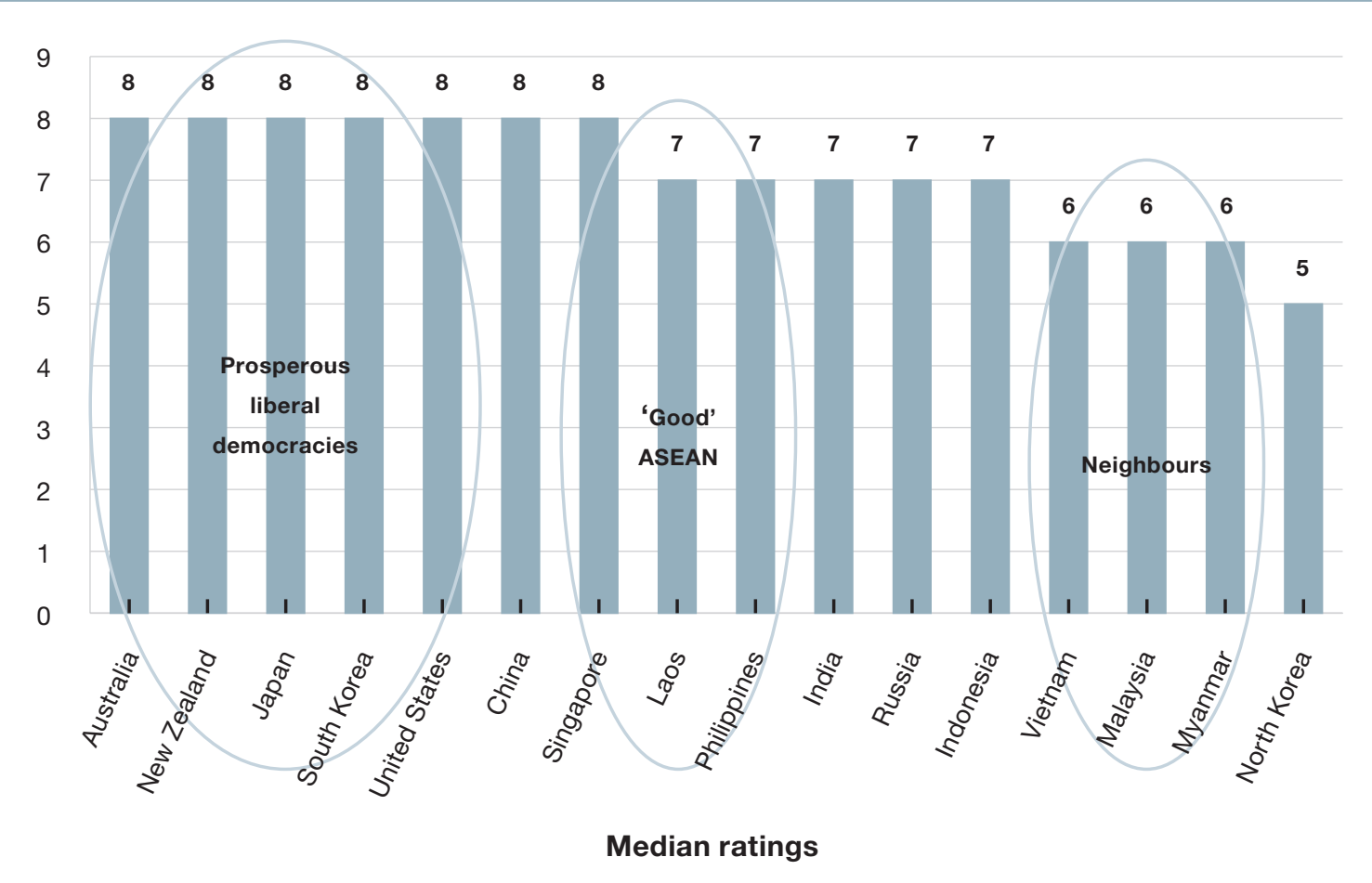




\section{Threat Perceptions of the Great Powers}

How do the Great Powers rank in Thai eyes? Very few of our survey respondents and interviewees believed that any other country, neighbouring or otherwise, poses any imminent threat to Thailand. So it is within this generally sanguine outlook that we consider why Thailand sees the United States as the largest potential Great Power threat, followed by China, Russia, Japan and India in descending order.

We advance two hypotheses. Firstly, fear of the United States interfering in Thailand's domestic politics is the most potent factor underpinning the rating. Secondly, historic amnesia has set in swiftly for many as far as recalling the US's Cold War support and China's Cold War threat.

\section{Great Powers and Thai domestic politics}

United States criticism of Thailand since the 2014 coup might be behind the United States appearing a greater potential threat than China. We asked if Great Powers could significantly shape Thailand's domestic politics.

FIGURE 9 Great Powers and domestic politics.

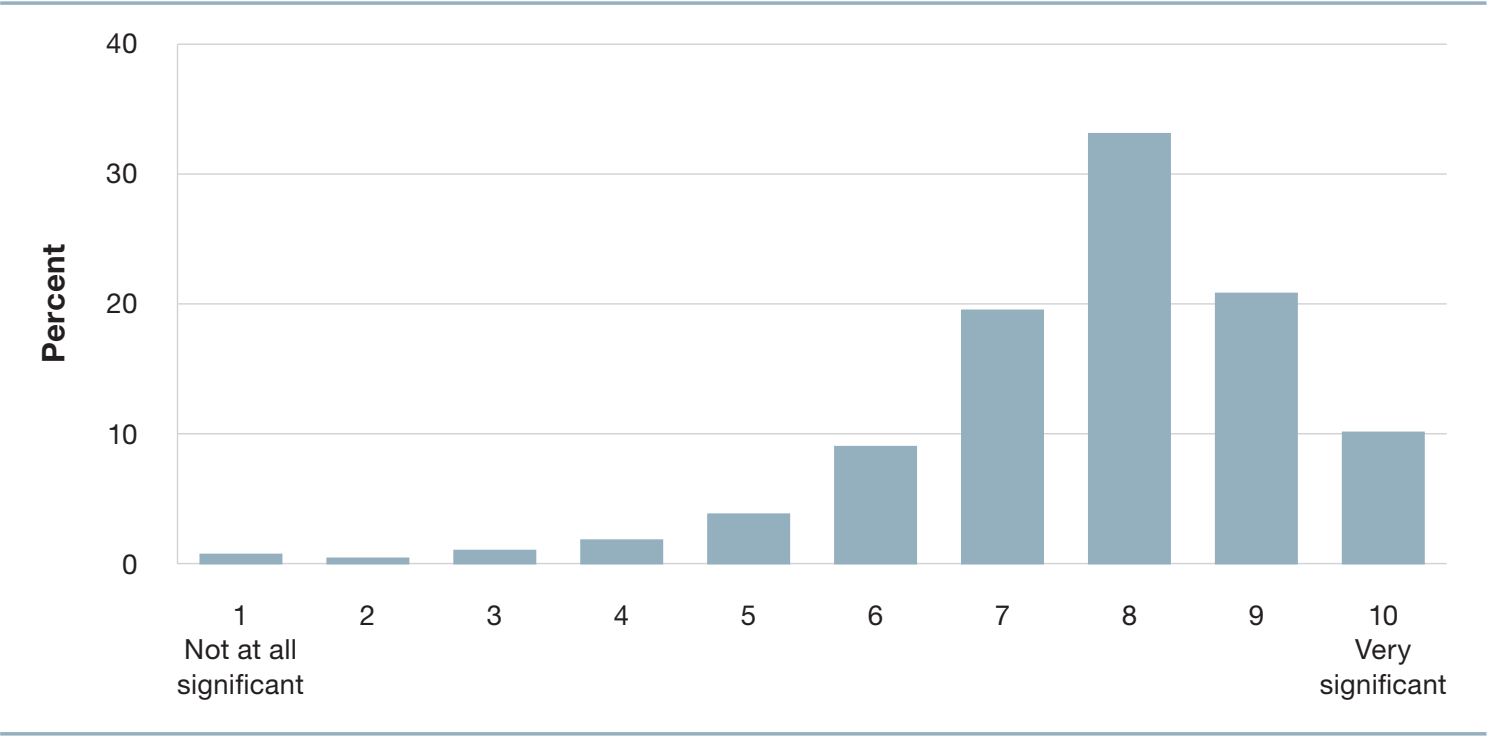

As shown above, respondents rated the capacity of Great Powers to interfere in Thai politics as high. At least some of the high threat rating for the United States stems from perceptions that the United States interferes in Thailand's domestic politics. This was shown through a correlation between threat ratings for Great Powers and belief that Great Powers can influence Thailand's domestic politics. The correlation was strongest in the case of the United States (compared with China, India, Japan and Russia). What lies behind this result?

The United States' vigorous condemnation of Thailand's 20 May 2014 coup is a major part of the story. This coup elicited a much stronger US response than the coup of 2006. In both cases the United States, as required by laws passed by the US Congress, suspended millions of dollars of security assistance provided under the International Military Education and Training (IMET) and Foreign Military Financing (FMF) programs. But in 2014 the suspension was accompanied by strong rhetoric and additional measures. ${ }^{2}$ High-level engagements, training programs and exercises were cancelled. According to Scot Marciel, Principal Deputy Assistant Secretary, Bureau of East Asian and Pacific Affairs, the "coup and post-coup repression" made it impossible for the United States to "go on with "business as usual."'3 Senior US officials drove the message home in public speeches on Thai soil. Senior US State Department official Danny Russell criticised the coup in a speech at Chulalongkorn University, saying that:

I'll be blunt here: When an elected leader is deposed, impeached by the authorities that implemented the coup, and then targeted with criminal charges while basic democratic processes and institutions are interrupted, the international community is left with the impression that these steps could be politically driven. 
Conservative Thais and large swathes of the Thai mainstream media reacted strongly to the criticism. There was a perception of US hypocrisy. Commentators noted Thailand was not getting the same treatment as other countries who had conducted coups; they doubted that 'the US would apply the same standards of engagement to all allies, such as Egypt or Israel. ${ }^{3}$ The Thai language press complained that the 'US really wasn't interested in democracy or human rights very much. It has supported coups in Egypt, Ukraine, Iraq, Iran, Algeria and other countries all over the world that help its national interests. ${ }^{5}$

Numerous interviewees cited the comparison with the United States treatment of the Egyptian's military. It was not the suspension of aid money that was at issue, it was the principle.

Thailand's sensitivity to criticism of its internal politics may be exacerbated by the past history of Great Power interference and influence in its domestic politics. After World War II, Thailand, having chosen to back the eventual loser, Japan, was vulnerable to foreign powers. Thai historians believe that CIA backing encouraged the first post-war military coup in 1947 and was instrumental in several ones thereafter. ${ }^{6}$

Today the internet and social media exacerbates fears of US influence and interference. Thailand has about 29 internet users per hundred citizens. ${ }^{7}$ After the 2014 coup, Facebook was abuzz with rumours that not only did the US not agree with the coup, it supported one side of Thai politics. Some even believed that the US had submarines in the Gulf of Thailand, ready to land troops to help this group.

\section{FIGURE 10 Social media "meme "with Thai mythical figure telling the Statue of Liberty not to interfere.}

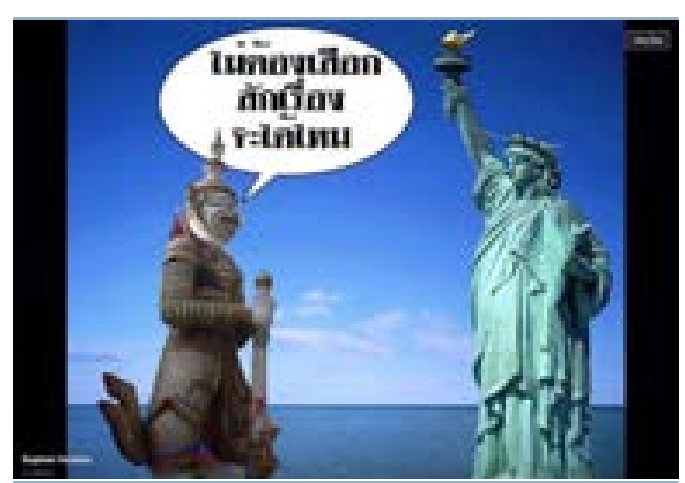

\section{Cold War Memory- The United States}

The criticism and fear belies the fact that Thailand was a huge beneficiary of US largesse during the Cold War. About \$USD 1 billion was spent on economic and military aid between 1946 and $1966 .{ }^{8}$ Designed to give Thailand greater logistics capacity to respond to threats from China or North Vietnam, US military construction included $563 \mathrm{~km}$ of asphalt road, airfields and the development of Sattahip port. ${ }^{9}$ The support also included education and training. By 1987, over 11,000 academics and civil servants had trained in the US under the US aid program..$^{10}$ The military aid budget was also generous..$^{11}$ This support, together with Japanese investment, helped Thailand emerge from the Cold War as a tiger economy. Thailand's per capita GDP by 2015 was 42 times what it had been in $1965 .{ }^{12}$

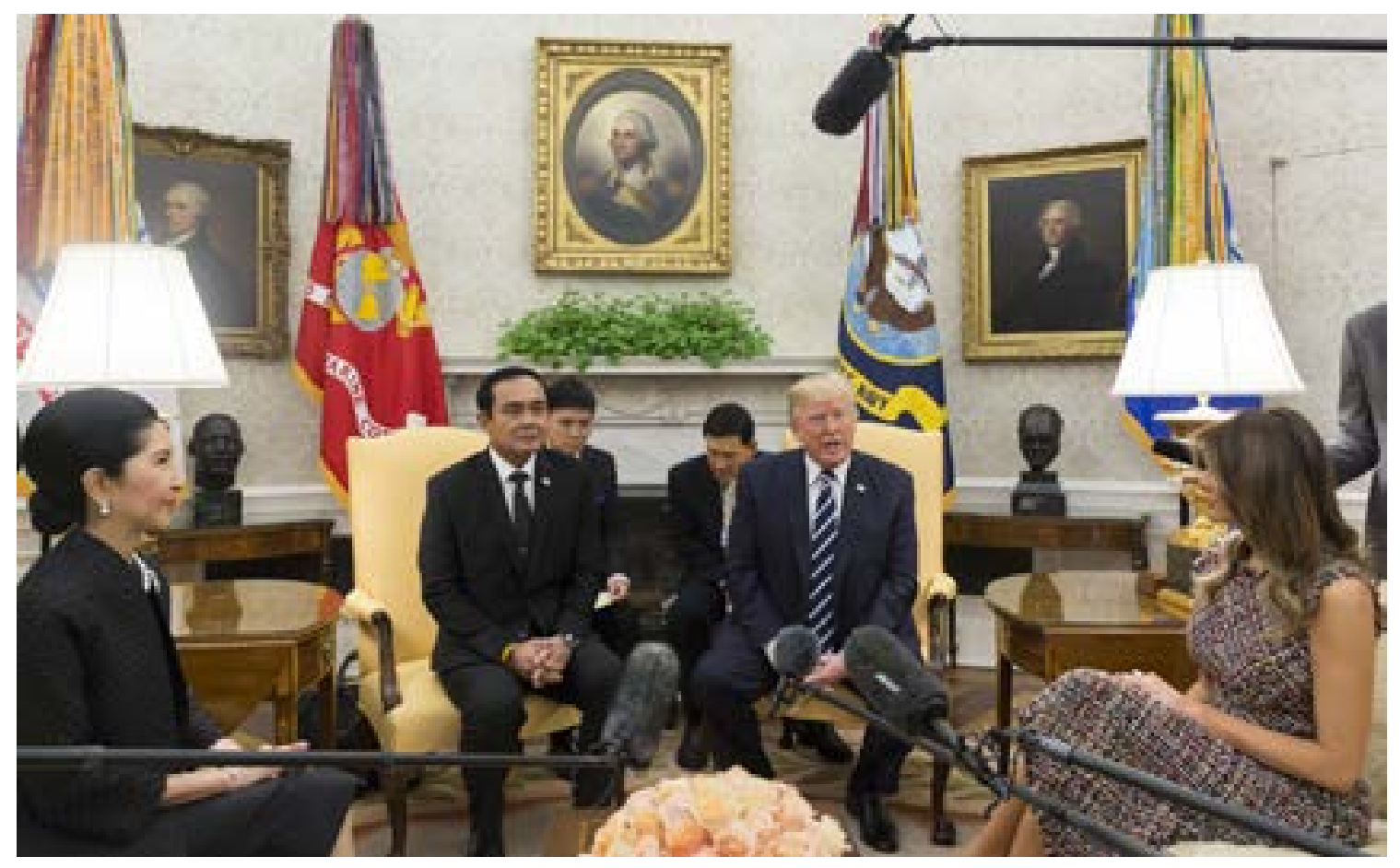




\section{Thais have limited} knowledge and mixed feelings about their Cold War enmeshment with the United States.

\section{FIGURE 11 Memory of SEATO}

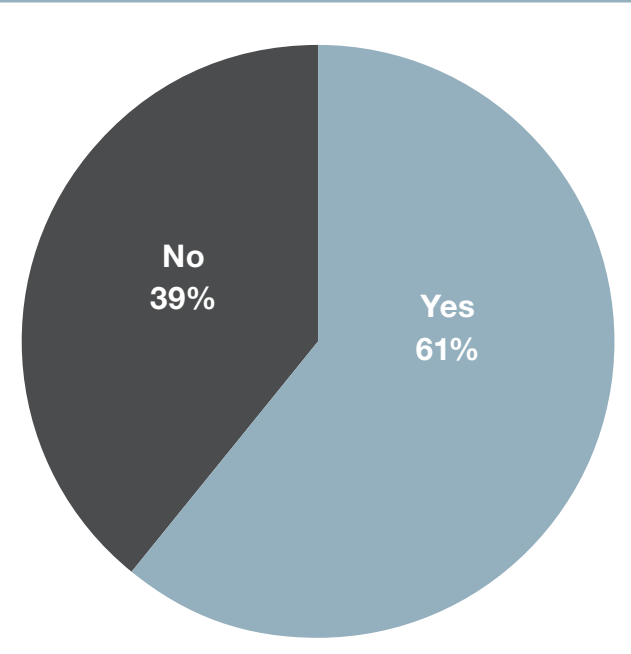

But today memory of the Cold War is less advantageous to the United States than might be expected. Thais have limited knowledge and mixed feelings about their Cold War enmeshment with the United States. We found that some two fifths of respondents were unaware of the Southeast Asian Treaty Organisation (SEATO), despite the 1954 Manila Treaty Pact, Thailand's alliance treaty with the United States, having established SEATO.

This partly reflects that officers who served in the Cold War period are long retired. It may also reflect that knowledge of the Cold War is found mainly amongst those who have pursued tertiary or self-directed studies in history. Feelings about Thailand's participation in the Vietnam War are mixed, and US forces left Thailand in 1976 under a cloud. Popular protest had forced Thai military dictators from office and the elected government was keen to draw a line under Thailand's involvement in the Vietnam War.13

In the intervening years some Thais regretted their country's involvement in regional conflicts, with some blaming the United States for having influenced their leadership. One former senior official told us that Thailand should not have accepted United States' views:

We were led to believe that communism is evil, China is a "yellow" evil, Vietnam is evil, mostly because of US propaganda. They were just like demons, threatening all countries in Southeast Asia.

In Thai popular culture the best known story of the Cold War highlights the social problems US forces left behind, such as Amerasian children. ${ }^{14}$ In contrast, the uninvited Japanese occupation from 1942 to 1945 is viewed nostalgically through the lens of a Thai-Japanese love story. ${ }^{15}$

\section{Cold War Memory - China}

China has in contrast benefited from the post-Cold War passage of time. In 2015 Thailand and China marked 40 years of diplomatic relations with lavish functions. Official statements spoke of a "close and cordial relationship, based on the solid foundation and deep bonds of affinity and cultural ties rooted since time immemorial."16

Airbrushed from this picture were the hostile Sino-Thai relations of the Cold War, when Thailand saw itself as "no exception to Peking's grand design for conquest and expanding influence."17 The Chinese Communist Party maintained links with the Communist Party of Thailand until 1979, broadcasting propaganda hostile to the Thai government from a radio station in Yunnan province. China had also granted asylum to former Thai prime minister turned rebel Pridi Phanomyong, who used Beijing to call for the overthrow of the Thai government. ${ }^{18}$

Thailand's decision to establish diplomatic relations with communist China in 1975 was based on hard geopolitical thinking. It was summed up by former US Secretary of State Kissinger in 1976:

With the collapse of our efforts in Indochina, the Thais, who were loyal allies during the war and relied on the United States, are looking for a different angle.....their assessment of the present situation is that ... North Vietnam ... must be counterbalanced ... by the People's Republic of China. It does not reflect hostility to the United States. ${ }^{19}$

Our military interviewees were aware of China's support for the Communist Party of Thailand (CPT) between 1950 and 1979. Nonetheless they told us that "We didn't see China as a combatant" in the Cold War. Another told us that there was a certain time period when China advocated exporting the ideology, and then up to a certain point, where diplomacy allowed a dialogue, a shift, where China engaged a country rather than a faction. 
Vietnam's invasion of Cambodia in 1979 tipped the Thai military view of China from foe into friend. With more Vietnamese troops in Cambodia than there were in Thailand's entire army, Vietnam was seen as a serious threat. Thus Thai military officers appreciated China's thrust into Vietnam's north in January 1979. This was the start of long running cooperation that included delivering weapons to Khmer Rouge rebels operating on Thailand's eastern border. ${ }^{20}$ This cooperation established strategic trust. Today many Thai military officers see China as a source of protection against external military threats, overlooking the irony of China's close ties to Cambodia today.

\section{FIGURE 12 Thailand's reliance on China for protection against military threats}

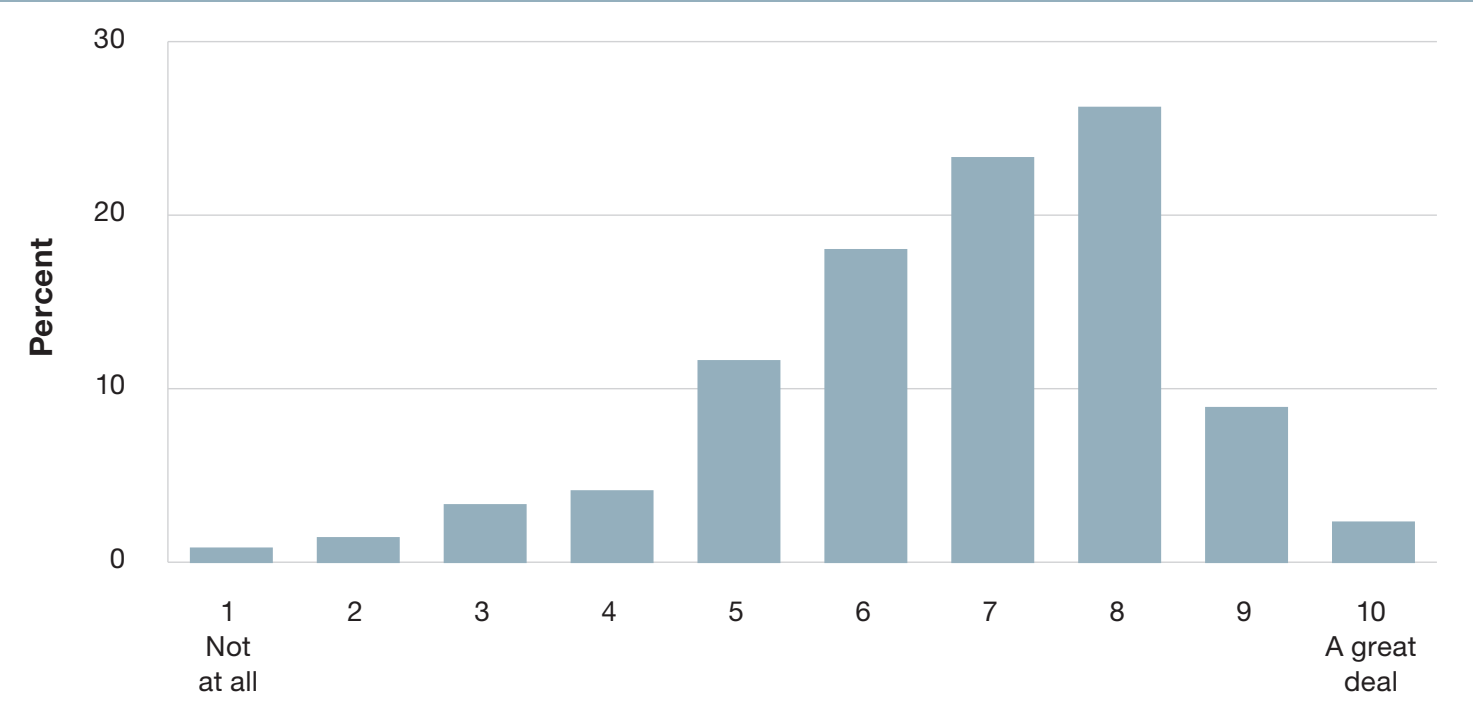

\section{The Sino-Thai Factor: How Important is it?}

Thailand's ethnic Chinese community [Sino-Thais] are Southeast Asia's most successful case of assimilation. Waves of migration from Teoh Chiuo, Hakka, Hokkien, Hainanese and Cantonese speaking provinces of southern China brought mostly male immigrants to Thailand in the late nineteenth and early twentieth centuries. They married local women, and frequently adopted Buddhism, Thai names and local customs. Arriving as labourers, their hard work, business acumen, and close family networks allowed them to move into the commercial strata of Thai society. Today Sino-Thais make up an estimated one third to one half of Thais living in Bangkok. ${ }^{21}$ Sino-Thai families are prominent and influential in Thailand's business community, and have played significant roles in forging Thailand's trade relationship with China. ${ }^{22}$

So do ethnic Sino-Thais in the Thai military shape attitudes toward China and the United States? During the 1950s citizenship rules blocked Sino-Thais from entry into the Thai military. Moreover the military was unpopular amongst SinoThais even after citizenship rules changed. ${ }^{23}$ But our surveys showed that today Thais with Chinese ancestry make up a similar proportion of today's officer ranks as in the general Bangkok population.

However, we also found that this Sino-Thai cohort does not hold views significantly different from the non-Sino-Thai respondents on the vast majority of the issues we tested. For example, they saw the relative influence and threat of the Great Powers in the same way as the remainder of the respondents.

\section{FIGURE 13 Sino-Thais in the Thai military.}

80

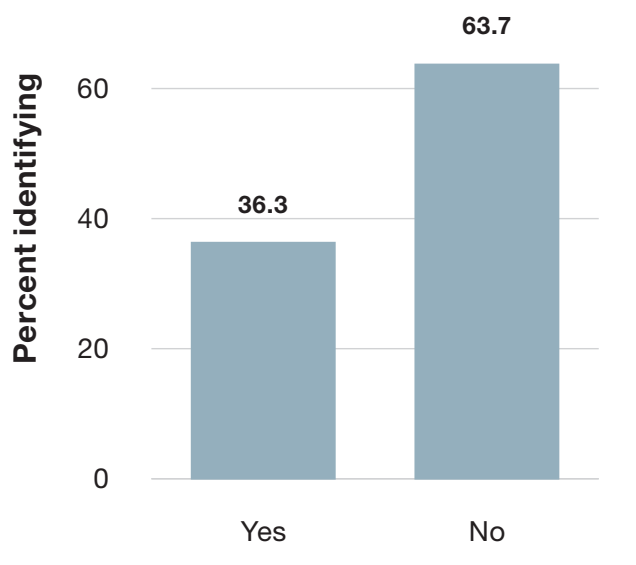


FIGURE 14 Responses by ethnicity when asked if Thailand should support China's claims in the South China Sea

30

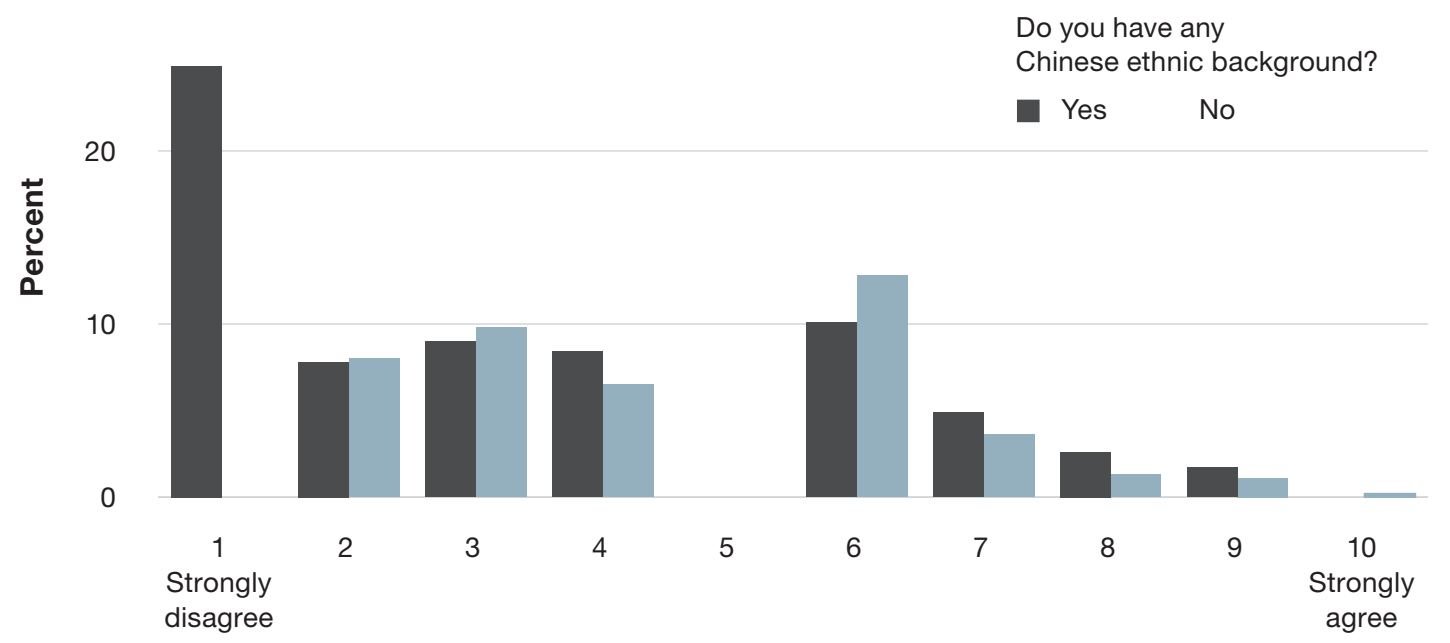

Interviewees tended to dismiss the significance of the Sino-Thai ancestry in Thai foreign policy. "It can influence some I think but...Thailand is Thailand and China is China." When we asked whether SinoThai backgrounds might boost the relationship with China at the expense of the United States they said "We've never thought about that."

\section{Procurement choices: what can they tell us?}

Thailand's decisions to acquire military equipment from China have been cited as evidence of a growing political alignment with China. ${ }^{24}$ Preparedness to procure significant capabilities indicates trust because of shared awareness of the strengths and limitations of the platform. But there are other factors in procurement decisions. We found that price was considered the most important reason for the attractiveness of Chinese military equipment.

FIGURE 15 Views of Chinese military equipment.

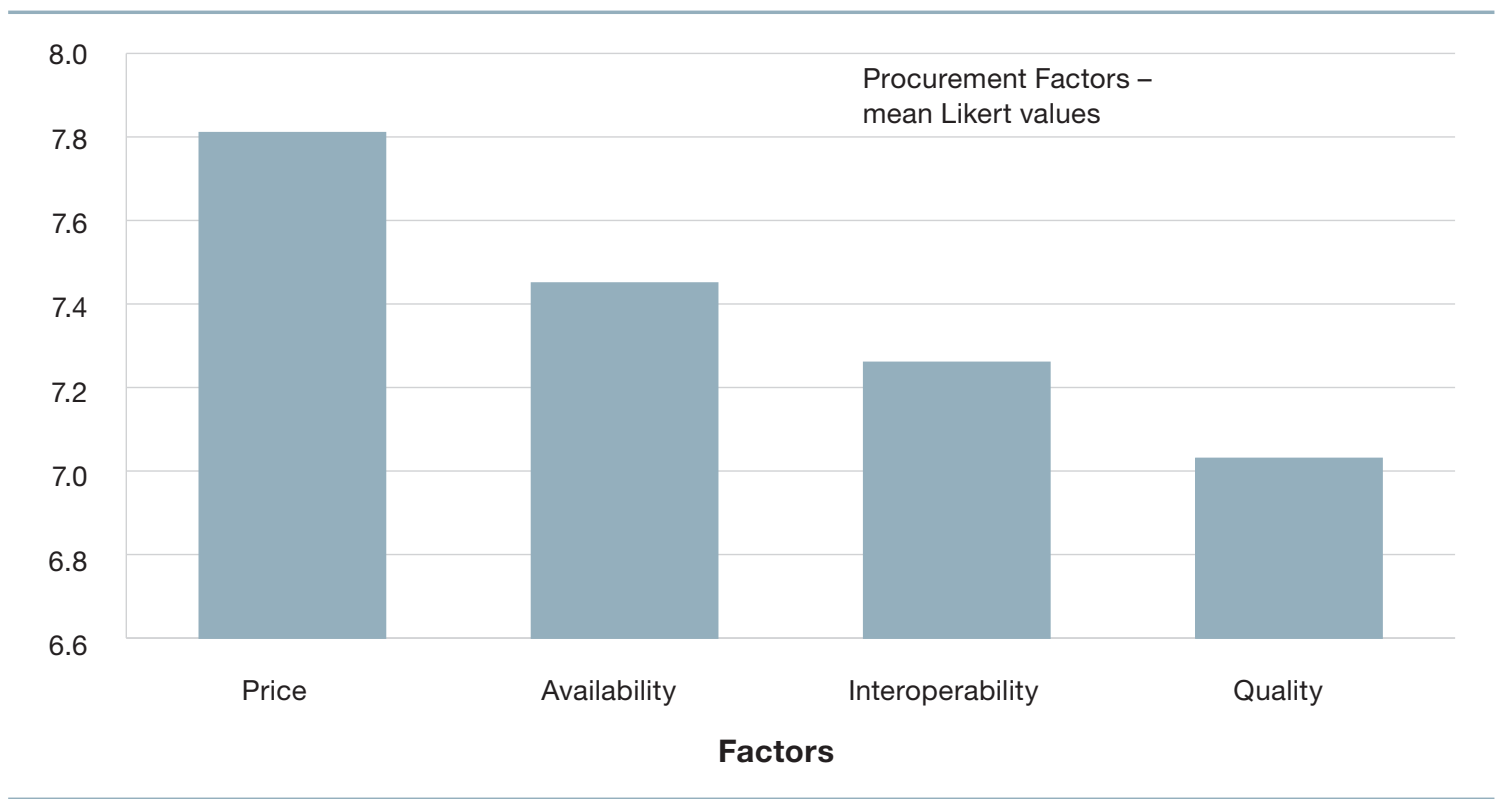


Chinese conventionally-powered submarines are indeed much cheaper than comparable Western alternatives. Thailand plans to spend USD\$1bn on three Chinese submarines compared with Australia's plan to spend USD\$39bn on twelve submarines from France. ${ }^{25}$ But price is not the only factor. We heard from many officers that the Thai military prefers US equipment but resents the unreliability of the US as a supplier, as well as the conditions it imposes:

The Americans agreed to sell the AMRAAM air to air missile. But they said you can buy it but you cannot keep it. Why not, it's our money? You buy it but you cannot have it. You have to keep it in the US. And not just for the airforce, also for the navy. ... A lot of process, a lot of limitations. So we have to buy somewhere else, we have to buy the Grippen. We would love to have the US fighter.

\section{American assets as China rises}

Thai perceptions of the United States as an interfering power, as well as unfavourable memories of the Cold War, and a belief amongst Thai officers that China's influence will continue to rise, all suggest a bleak picture for the future of the United States - Thailand military alliance. However this is far from a complete picture. The breadth and depth of the United States -Thai alliance remains significant, with assets and advantages that it can leverage going forward.

To begin with, it is likely that the relationship will rebound somewhat as soon as Thailand holds elections and USimposed limits on military cooperation are lifted. The current political dynamic is clearly unfavourable for the strategic and defence relationship. Several of our interviewees made this point, including a former foreign minister who noted that "we remain friends, and eventually this will pass."

This rebound should not be overstated. The relative economic decline of the United States, the diversion of US attention away from Thailand and Southeast Asia more generally in the post-Cold War era as well as the increasingly faint memory of Cold War intimacy all mean that some overall diminishment of influence will be irreversible.

We believe, nonetheless, that two other factors will help keep the US -Thailand alliance viable and healthy into the future, even if different to the past. The first is the institutionalising of English language usage and United States military doctrine in the Thai military. The second is Thailand's strategic culture, which means that Thailand is strongly inclined to maintain multiple relationships with Great Powers, as well as cultivating another proto-Great Power, ASEAN.

\section{Language and doctrinal advantages}

Language and doctrine favour the US alliance rather than China. The second language of Thai military officers is overwhelmingly English rather than Mandarin Chinese. Although there is a small and increasing number of Thai officers studying Mandarin Chinese, it is not widely taught or spoken in Thailand (ethnic Sino-Thais generally speak Teoh Chiou) and the officers returning from language study struggle to maintain their skills. ${ }^{26}$ Anecdotally, Thai elites and middle class still prefer to send their children to be educated in the United Kingdom and the United States. The institutionalisation of English and US doctrine is not irreversible but the cost of changing to Chinese language and Chinese doctrine would be significant and therefore not likely in the foreseeable future.

Doctrinally, the Thai military is very close to the United States, having adopted US military doctrine in the 1950s. As one officer told us, procurement from countries other than the United States has not changed this:

For example, even though we have the Grippen combat aircraft, we still use the US doctrine. We use the Chinese tank but still use US doctrine. We study it in the Command and General Staff College. The organization of our units is also still based on the US. 
High volumes of training and exercises with the United States and other US-oriented powers, reinforce Thai use of English and US doctrine. Some 21,000 Thai officers had trained in the United States by the early twenty-first century. ${ }^{27}$ Although the numbers fell from the years of the Vietnam War, when the US trained 1500 officers per year, they remained substantial during the early 1990 s at 350 per year. ${ }^{28}$ With the restrictions put in place after the May 2014 coup, 1084 Thai military personnel trained in the US in 2014, 244 in 2015, and 103 in 2016..$^{29}$ Yet there are still some 60 joint exercises annually. ${ }^{30}$

The breakdown of the officers we surveyed suggests that the United States remains by far at this point the leading foreign provider of education and training to Thai military officers.

\section{FIGURE $16 \%$ of respondents according to foreign country study} (2015, 2016 and 2017 data).

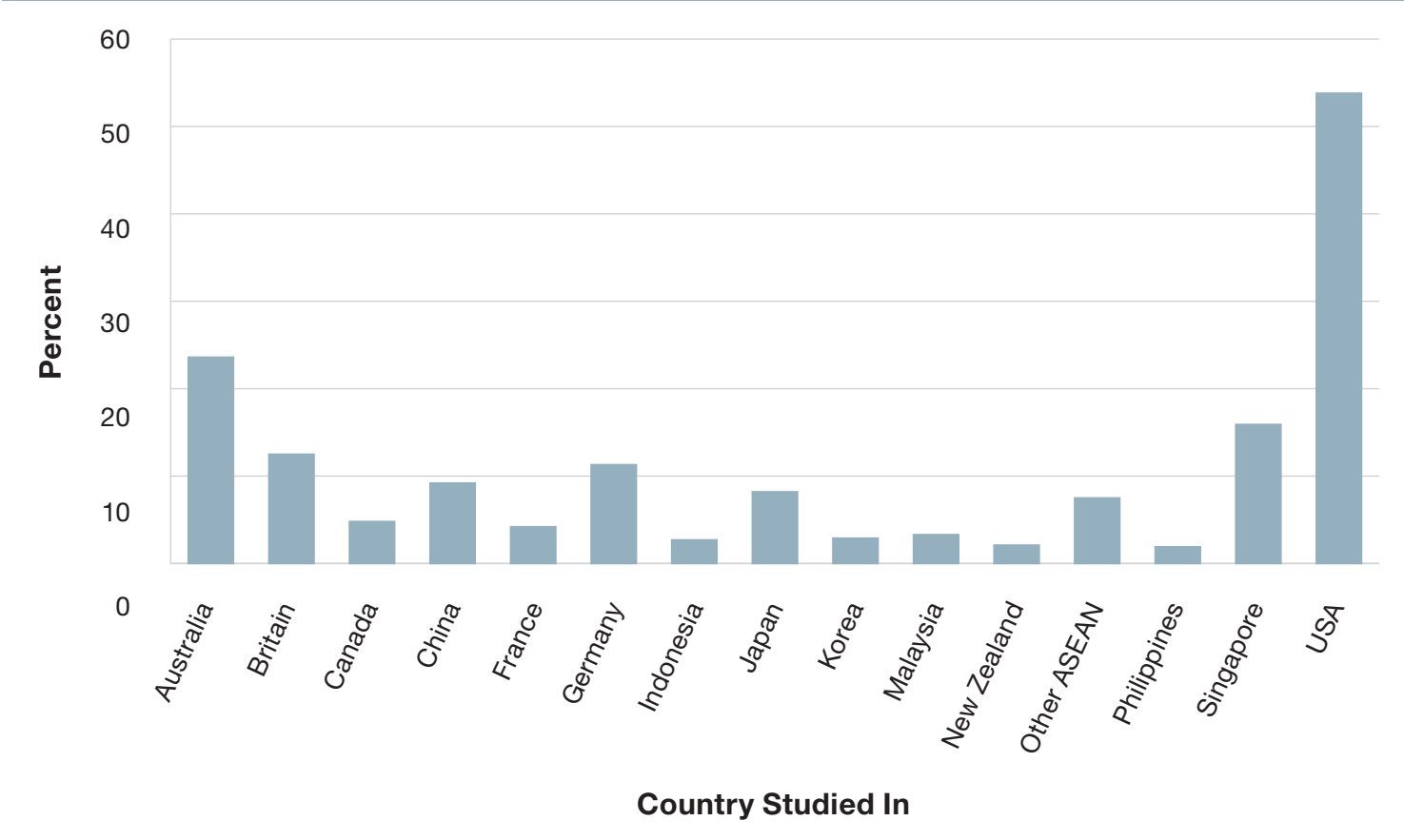

This chart to some extent places the growth in the China-Thailand bilateral defence relationship in perspective. Certainly it needs to be recognised that there have been a number of significant 'firsts' in the China -Thailand bilateral defence relationship in recent years. The first combined air force exercise (Falcon Strike) took place in 2015, reportedly involving as many as 180 Chinese officers and pilots. ${ }^{31}$ Falcon Strike follows the first combined China-Thailand marine exercise in 2010 (Blue Strike) and the first combined China-Thailand army exercise in 2007 (Strike). But the significance of these should not be overemphasised. Critically, the language barrier limits the extent to which the exercises can resemble real combat or develop interoperability. As one Thai officer told us:

it's very dangerous, flying the Chinese and American airplanes together and you can't speak the same language. The "Falcon Strike" exercise; people think it means they have been training together; it's more like "we fly, they fly". It's not the joint training such as we do with Australia or the US. Interoperability with the Chinese is still a long way off.

\section{Thailand's strategic and foreign policy culture}

Thailand's renowned preference for an omnidirectional foreign policy remains strong amongst both Thailand's military and diplomats. We frequently heard interviewees stress the importance of balance in foreign relations. Some explicitly referenced the example of nineteenth century monarch Chulalongkorn, who famously preserved Thailand's independence despite the close attention of predatory European powers France and England. This principle suggests that Thailand will aspire to 'balance' its relations with major powers to ensure that none gain disproportionate influence, giving Thailand a degree of freedom in its posture. It suggests that even as China's influence grows, Thailand will seek to have strong relationships with other powers, particularly the United States, but also with regional powers India and Japan. 
It is certainly the case that, notwithstanding the threat perceptions and tensions in the bilateral relationship, Thai military officers still place great store on the United States for security.

FIGURE 17 Reliance on the United States for security.

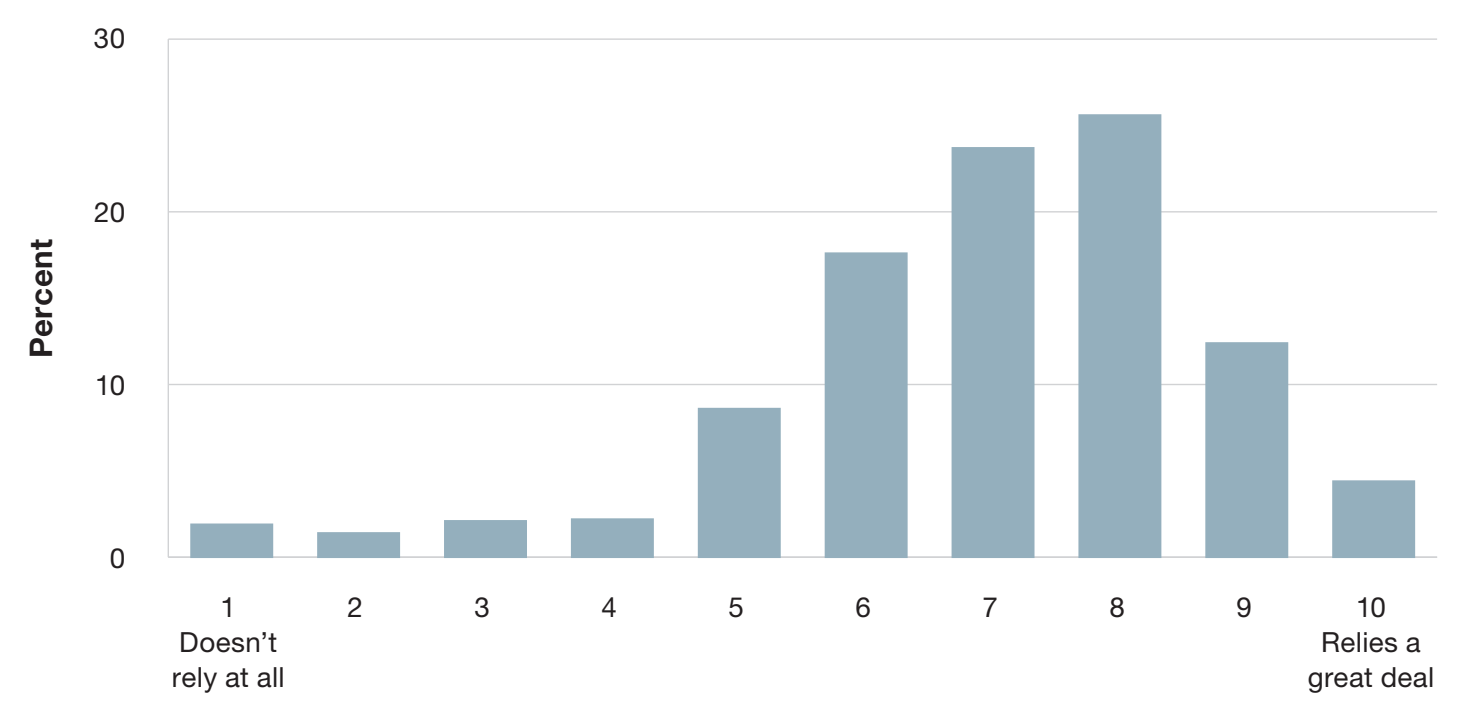

One officer told us that "We don't want the Chinese to do what they want, that's why we appreciate the US coming into the region to be another big guy on the block. To make sure the one big guy we have is not pushing people around." This suggests that the Thai military will not relinquish their close relationship with the United States easily. Indeed, some of our interlocutors emphasised that the closeness of the military-to-military relationship has remained unruffled by the turbulence at the political level, reminiscent of the way in which relations between the Australian Defence Force and Malaysian Defence Force were little affected by ruptures in diplomatic and political ties in the 1980s and 1990s. ${ }^{32}$

There will however be one important difference between now and Chulalongkorn's era- ASEAN. It is clear that Thailand's foreign policy portfolio will continue to include investment in ASEAN. Thai elites vary in their view of ASEAN. Some retain the view that it can help to restrain the influence of major powers, while others emphasize the market potential that a combined population total of 620 million people can offer. The survey results suggest that ASEAN is seen as more important for Thailand's prosperity than its security.

\section{FIGURE 18 Importance of ASEAN for regional prosperity}

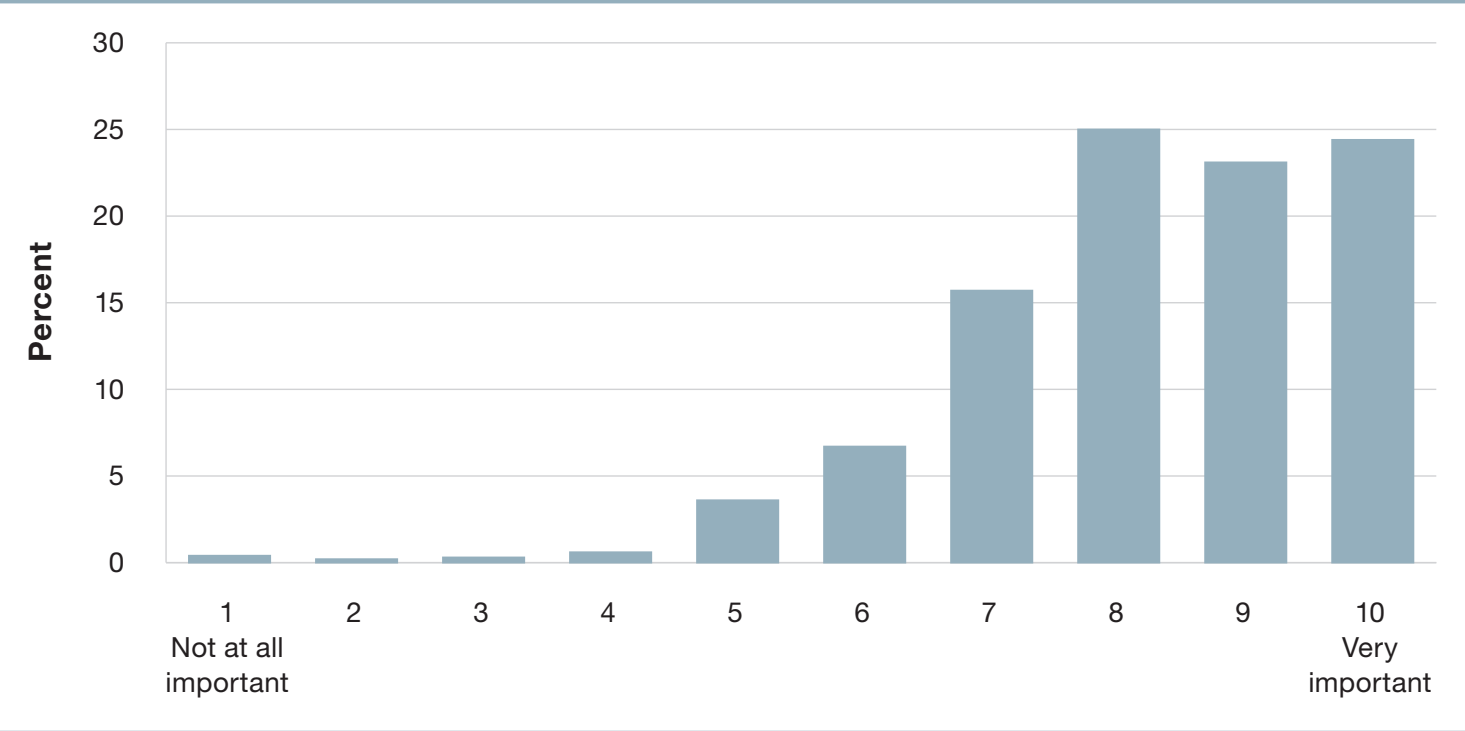




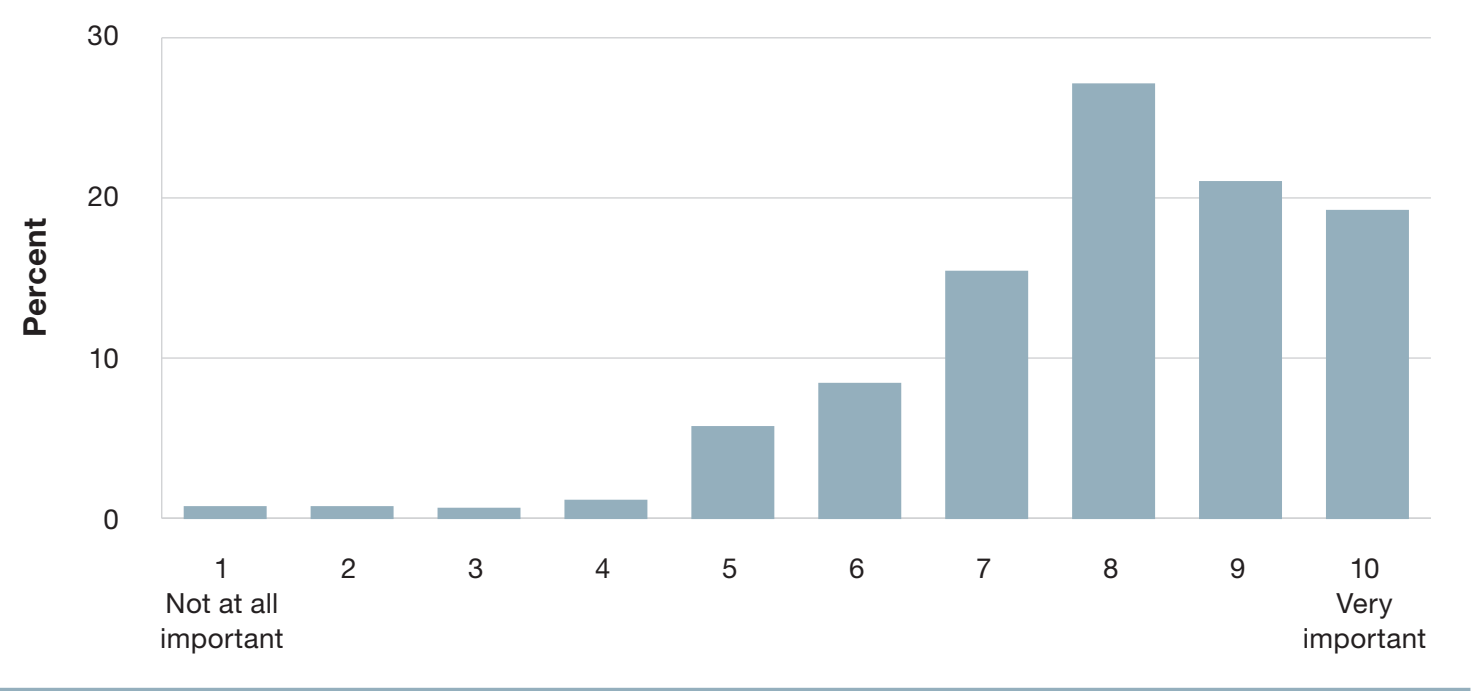

\section{Conclusion}

During the 1980s and 1990s China became more trusted through both its military aid in the years of the Cambodian crisis, and its financial aid following the 1997 financial crisis. In 2012 it became Thailand's largest trading partner. China's prosperity and proximity mean it will become increasingly important and influential in Thailand. As long as China continues to hold to its non-interference principles, it can expect considerable respect and goodwill at a political and commercial level. China's cultural diplomacy in Thailand, whether through its 15 Confucius Institutes, the cultivation of Thai Royal, Princess Sirindhorn (who speaks Chinese and is accomplished in Chinese arts such as calligraphy), or emphasis of historic linkages will assist. ${ }^{33}$ China can expect a degree of accommodation of its interests from Thailand in areas such as terrorism and human rights, as well as strategic matters. ${ }^{34}$ This could in future affect some US-Thai defence cooperation, such as surveillance flights from Thai territory.

\section{China's prosperity and proximity mean it will become increasingly important and influential in Thailand.}

But there will be limits. Thailand values its sovereignty and there will be resistance to proposals which are perceived to infringe this. Thailand for example, resisted China's proposal for joint patrols on Thailand's sections of the Mekong River. ${ }^{35}$ And rub points do exist. Negotiations on the high-speed railway project have been unexpectedly protracted and difficult. The growing numbers of Chinese tourists, while important to Thailand's economy, are seen as rude and ignorant of local customs and laws. ${ }^{36}$ China's dam building and control of water on the Mekong is a longer term but growing concern.

The place of the United States has changed in the Thai psyche, as has Thailand in the United States' strategic horizons. The strong and mutual perceptions of threat that first arose after North Korea's invasion of South Korea in 1950, and which saw the signing of the Manila Pact in 1954, have long since receded. ${ }^{37}$ Thailand will continue to value its alliance with the United States, but it will also believe in its own capacity to navigate the increasingly more multipolar strategic environment of the twenty-first century. This will be a viable approach, providing China and the United States avoid war.

Thailand's domestic politics, and in particular the state of its democracy, will continue to influence its foreign policy perceptions. The future trajectory for Thai democracy remains uncertain. Although elections are scheduled for 2018, the current royal transition and the aftermath of the 2014 coup have prompted the Thai military to seek a tighter grip on Thai politics than after the 2006 coup. Constitutional levers of control over the next elected government have been installed, but questions remain over how effective these will be. A clear return to democracy would be better for the US- Thai alliance. 
1. Modulate approaches for advocating on democracy. A democratic Thailand is a better partner and a more positive influence for the region. Hence partner countries should continue to advocate for a return to democracy, but in ways less likely to be construed as lecturing, condescending, interfering or taking sides. Representations in private bilateral meetings, where diplomats and officials should communicate a principled but respectful stand, are less likely to be construed negatively. Similarly, a broader program of engagement on democratic processes and principles will communicate support for the values of democracy and human rights, without being seen as "naming and shaming". Counterpart exchanges and contact between equivalent institutions such as houses of parliament, electoral commissions and governance think-tanks such as Thailand's King Prajadhipok Institute could be considered. On the other hand, the need for public speeches addressing issues such as lèse-majesté, and elections should be carefully considered, lest they set the tone for the bilateral relationship.

2. Support more historical reflection. The Cold War period of alliance cooperation is now largely obscured from Thai public memory and popular culture, probably to the US's disadvantage. There may be value in encouraging a more active debate and reflection in Thailand about the period. This reflection would be best led by non-government actors, including Thai and overseas researchers. Funding should be allocated for historical scholarship and workshops, with Thai, US and international participation, on Cold War topics to encourage a more mature and balanced understanding of this important period.

3. Foster cultural and linguistic sensitivity. Partner countries can narrow the distance between themselves and Thais by demonstrating that they can operate in the same cultural and social world. The US Embassy, for instance, should have a greater association with the Thai language. It should issue publications in Thai. The US Ambassador, even if not a Thai speaker, should engage Thaispeaking assistants and translators, to allow him/her to communicate, including through social media, in Thai.

4. Support ASEAN. Although not without sceptics, ASEAN has overall increased in importance in Thai thinking about its future. Partners should demonstrate an awareness and support for ASEAN goals and programs. They should highlight and publicise their own engagement with ASEAN, for example with Ambassadors to ASEAN resident in Jakarta. They should seek opportunities for ASEAN-partner country cooperative activities to be held in Thailand.

5. Avoid zero-sum views on Thailand and China. The Sino-Thai relationship should be seen for what it is: a very rich, long, deep and complex relationship that cannot be easily encapsulated. There have been many ups and downs, and there will be more in future, as Thailand starts to worry about issues such as the management of the Mekong River. The Sino-Thai lineage of many in Bangkok is much more important with respect to culture and business links than to political and security links. On the latter Thailand's own strategic culture is far more influential. Nonetheless geography means there is an inevitability regarding China's influence reaching greater levels. Thailand, in the end faces many of the same questions that other regional countries do, regarding how to accommodate a rising great power and source of economic growth while at the same time pushing for the retention of a rules-based global order that, backed by American military preponderance, has delivered immense benefit.

6. Engage on environmental challenges. With the waning of great power competition after the end of the Cold War, Thailand and other ASEAN member states have developed a keen interest in nontraditional security matters. One aspect of this which is generating genuine worry concerns potential massed migration arising from likely food and water shortages arising from climate challenges and a massive over-damming of the Mekong River. Support for Thailand over emerging environmental challenges, particularly concerning emerging water management problems on the Mekong River, has the potential to generate considerable benefits. 


\section{Annex: Notes on Method}

Surveys in Thai were filled out in hardcopy by military officers studying in Thai military educational institutions including service academies, staff colleges and war colleges. We also surveyed a group of businesspeople and bureaucrats studying at the King Prajadhidpok Institute, a government-funded institute. The make-up of the respondents in terms of military and civilian mix, service, age, rank, religion, educational attainment and regional background is shown below.

We supplemented this statistical data with qualitative data from over twenty interviews with senior Thai leaders, including former ministers, senior military commanders, and middle-ranking officials and military officers.

\section{FIGURE 20 Demographic data.}
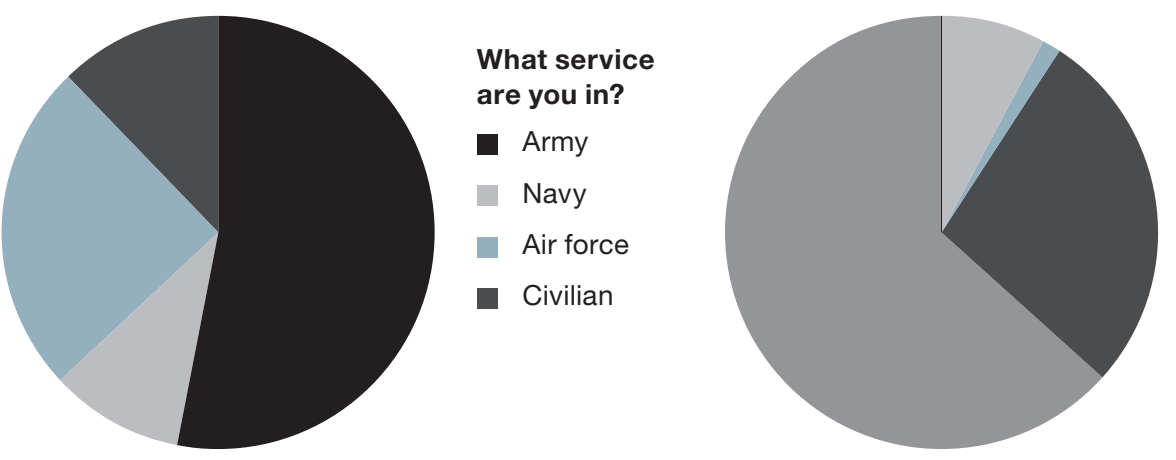

How old

are you?

- $18-20$

- 21-24

- 25-30

- 31-35

36 or over

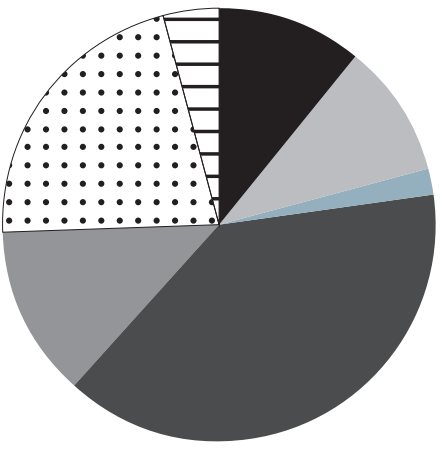

What is your rank?

- Civilian

- Officer cadet

- Lt/Capt

- Major

Lt Col

oㅣ

每 Above Col

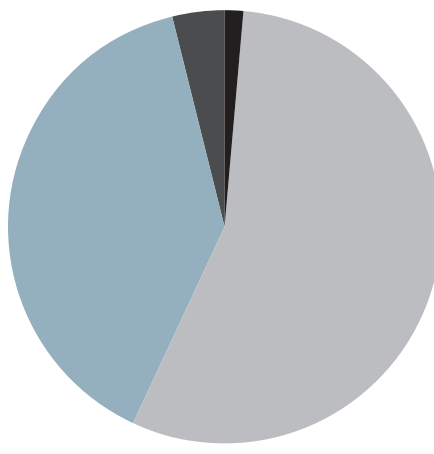

What is your highest educational qualification?
- High school diploma
- Bachelors
- Grad dip / masters
a PhD

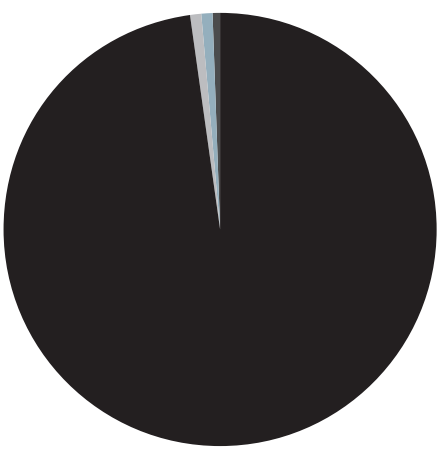

What is your religion?

- Buddhist

- Christian

- Muslim

Other

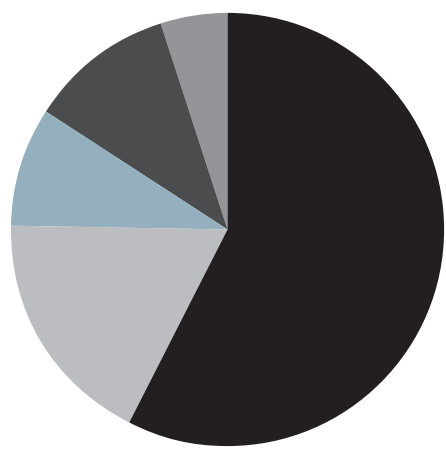

Which region do you come from?

- Central

Thailand

Northeastern

Thailand

- Southern Thailand

- Northern Thailand

- Eastern

Thailand 


\section{Recommendations}

$\&$ Modulate approaches for advocating on democracy. Partner countries should continue to advocate for a return to democracy, but in a way that is less likely to be construed as interference or taking sides. The focus should be on representations in private meetings and a broad program of engagement on democratic processes and principles.

$\&$ Support more historical reflection. Historical scholarships and workshops should be provided on Cold War topics to encourage a more mature and balanced understanding of the period.

$\&$ Foster cultural and linguistic sensitivity. Partner countries should have closer engagement with messages conveyed in the Thai language.

$\&$ Support ASEAN. Partner nations should demonstrate an awareness and support for ASEAN goals and programs.

$\leftrightarrow$ Avoid zero-sum views on Thailand and China. The Sino-Thai relationship is rich, long, deep and complex. But Thailand's own strategic culture is more influential on its national security choices.

$\leftrightarrow$ Engage on environmental challenges. Thailand and its neighbours have developed a keen interest in non-traditional security matters including massed migration, water shortages and over damming of the Mekong River. Support for countries like Thailand over emerging environmental challenges has the potential to generate considerable benefits.

\section{Endinotes}

1 As historian Patrick Jory points out Thailand "was one of the first Asian kingdoms to leave China's tributary system in the mid-nineteenth century and effectively substitute imperial China's hegemony for that of the British Empire." Patrick Jory, 'Enter the dragon: Thailand gets closer to China', The Interpreter, 14 August 2017.

2 Scot Marciel, Principal Deputy Assistant Secretary, Bureau of East Asian and Pacific Affairs

Testimony Before the House Committee on Foreign Affairs Subcommittee on Asia and the Pacific, Washington, DC, 24 June 2016 downloaded at http://bangkok.usembassy.gov/062414_scot_marciel_testimony.html on 25 Feb 2016.

3 Ibid.

4 Kavi Chongkittavorn, 'US political posturing kills US-Thai relations', The Nation, 20 July, 2015.

5 Dr Arnon Sakwirawit, 'Panda Gold versus Cobra Gold', Thai Post, 2 June 2014, p.4 57255289.

6 Phleerng Phuuphaa, สงครามกลางเมือง กบฏ แมนฮตตัน Civil War: the Manhattan Rebellion (Bangkok: Siam Knowledge, 2015).

72013 figures. The Nation, 20 July 2015.

8 Moshe Lissak, Military Roles in Modernization: Civil-Military Relations in Thailand and Burma, (London: Sage Publications, 1976), p. 94.

9 Robert J Muscat, Thailand and the United States: Development Security and Foreign Aid, (New York: Columbia University Press, 1990), p. 65.

10 lbid.

11 Between 1951 and 1971, US military assistance to Thailand was equivalent to half the Thai military's own budget. Chai-Anan Samudavanija, Kusuma Snitwongse and Suchit Bunbongkarn, From Armed Suppression to Political Offensive: Attitudinal Transformation of Thai Military Officers Since 1976, (Bangkok: Institute of Security and International Studies, Chulalongkorn University, 1990), p. 21.

12 That is, USD\$5,820. Asian Development Bank, ADB and Thailand: A Development Partnership Toward Inclusive Growth, (Thailand: Asian Development Bank, 2017), p. 4.

13 The ugly Mayaguez incident, in which US marines staged a military operation against Khmer Rouge forces from Utapao airbase without prior Thai government authorisation, further soured relations. Foreign Relations of the United States, 1969-1976, Volume E-12, Documents on East and Southeast Asia, 1973-1976. Telegram 8690 From the Embassy in Thailand to the Department of State, May 13, 1975, 13152.

14 Khao Nok Na (Rice Outside the Field) was published in 1973, tracing the lives of two Amerasian half-sisters. It won a national prize for the best novel of that year, and feature film and television series versions were subsequently produced.

15 The popular Khu Kam (Destiny Couple) was published in 1972 and tells the story of a Japanese soldier hero Kobori and his Thai lover.

16 'Congratulatory messages on the $40^{\text {th }}$ Anniversary of the establishment of diplomatic relations between the Kingdom of Thailand and the People's Republic of China. <Downloaded at http://www.mfa.go.th/main/en/media-center/1457905Congratulatory-Messages-on-the-40th-Anniversary -of.html>on 11 August 2017.

17 Statement by Thai representative Sukich Nimmanhaeminda in the UN General Assembly on Chinese representation in the UN, 24 November 1966 in Rajendra Kumar Jain, China and Thailand 1949-1983, (New Delhi: Radiant Publishers, 1984), p. 123. 
18 'Article by former Thai Premier Nai Pridi Phanomyong in 'People’s Daily, 29 July 1954', in Rajendra Kumar Jain, China and Thailand, 1949-1983, (New Delhi: Radiant Publishers, 1984), 23.

19 R. Sean Randolph, The United States and Thailand: Alliance Dynamics, 1950-1985, (Berkely: Institute of Asian Studies University of California 1986).

20 Michael R. Chambers, 'The Chinese and the Thais are Brothers': the evolution of the Sino-Thai friendship, Journal of Contemporary China, 14:45, 599-629, 2005, DOI: 10.1080/10670560500205100.

21 Maurizio Peleggi, Thailand: the Worldly Kingdom, (London: Reaktion Books, 2007).

22 The conglomerate Charoen Pokhphand (CP Group), was an early investor in China. It was run by 2nd generation Sino-Thai Dhanin Chearavanon whose father was from Guangdong, and emigrated in 1921. During the 1980s CP was the world's single largest investor in China. Evan S. Medeiros, Keith Crane, Eric Higinbotham, Norman D. Levin, Julia F. Lowell, Angel Rabasa, Somi Seong. Pacific Currents: the Response of US Allies and Security Partners in East Asia to China's Rise, (Santa Monica: RAND Corporation 2008), p. 136.

23 Richard J. Coughlin, Double Identity: The Chinese in Modern Thailand, (Westport, Connecticut: Greenwood Press Publishers, 1960), p. 173.

24 'Thailand Tilts Away From the US', Wall Street Journal, 30 June 2015; 'US frozen out of defence deals', Bangkok Post, 23 May 2016; Thitinan Pongsudhirak, 'The submarine deal that won't go away', Bangkok Post, 12 May 2017; Patrick Jory, 'Enter the dragon: Thailand gets closer to China', The Interpreter, 14 August 2017; Adam Ramsey, 'Thailand is Finally Cozying Up to China- Why Now?', Ozy.com, downloaded at <http://www.ozy.com/fast-forward/thailand-is-finallycozying-up-to-china-why-now/79740

25 'France wins \$50b contract to help build Australia's new submarines', Sydney Morning Herald, 27 April 2016.

26 About twenty scholarships per year across the whole armed forces according to one officer.

27 Michael Connors, 'Thailand and the United States: Beyond Hegemony?', in Ed., M. Beeson, Bush and Asia: America's Evolving Relations With East Asia, (Routledge, 2006), p. 142.

28 Jennifer Morrison Taw, Thailand and the Philippines: Case studies in US IMET Training and Its Role in Internal Defense and Development, (Santa Monica: RAND, 1994), p. 22.

29 Department of Defense and Department of State, 'Joint Report to Congress: Foreign Military Training Fiscal Years 2013 and 2014 Volume 1', 'Joint Report to Congress: Foreign Military Training Fiscal Years 2014 and 2015 Volume 1' and 'Joint Report to Congress: Foreign Military Training Fiscal Years 2014 and 2015 Volume 1' downloaded at https://www.state.gov/t/pm/rls/rpt/fmtrpt/index.htm on 15 August 2017.

30 US Embassy \& Consulate in Thailand, Joint US Military Advisory Group Thailand (JUSMAGTHAI) downloaded at https://th.usembassy.gov/embassy-consulate/bangkok/us-agencies/jusmagthai/ on 15 August 2017.

31 Richard S. Erlich, 'China-Thailand joint military exercise shows longtime U.S. ally Bangkok hedging its bets', The Washington Times, 9 November, 2015.

32 Craig A. Snyder, 'Australia-Malaysia Security Cooperation as a Pivotal Components for More Stable Bilateral Relations', Asian Politics and Policy, 2015, Volume 7, Number 3, pp. 379-393.

33 Confucius Institute homepage, accessed at http://english.hanban.org/node_10971.htm on 16 August 2017.

34 See for example, Thailand's return of Muslim Uighurs. 'Thailand forcibly sends 100 Muslim Uighurs back to China and an uncertain future', The Canberra Times, 10 July 2015.

35 Ian Storey, 'Mekong River Patrols in Full Swing but Challenges Remain' China Brief volume 12 Issue 4, 21 February 2012 , accessed at https://jamestown.org/program/mekong-river-patrols-in-full-swing-but-challenges-remain/15 August 2017.

36 Atchak Satyanurak, Chamkat Nakthonghiao Chin Doi Duan, 'Limit Chinese Tourists Urgently', Prachatai, 28 February 2016

37 This applies equally to the Thanat-Rusk communique of 1962 in which the terms of the Manila treaty were explicitly linked to Thailand, independent of SEATO.

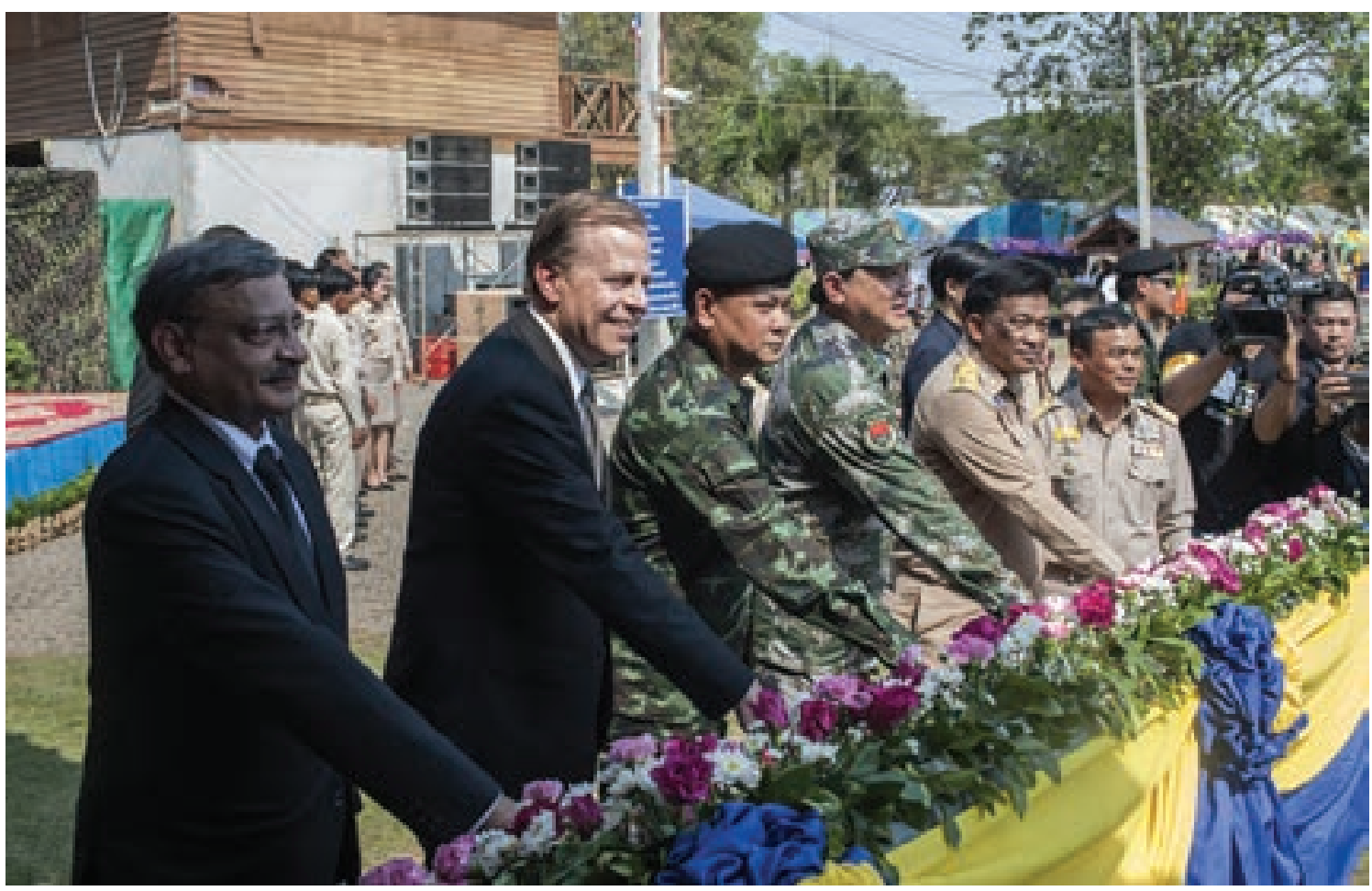




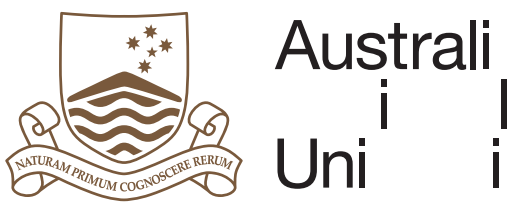

\section{MASTER OF STRATEGIC STUDIES}

\section{Australia's foremost Strategic Studies program, offered by the Strategic \& Defence Studies Centre, at the Coral Bell School of Asia Pacific Affairs}

A graduate degree combining the theoretical and practical expertise of leading academics and policymakers. Develop the analytical frameworks you need to tackle the regional and global strategic and security challenges of your career, and graduate a leader in your field. Students looking to undertake a major research essay under the supervision of a leading Strategic Studies scholar should consider the Master of Strategic Studies (Advanced) program.

\section{Major courses include:}

\section{STST8002 The New Power Politics of Asia}

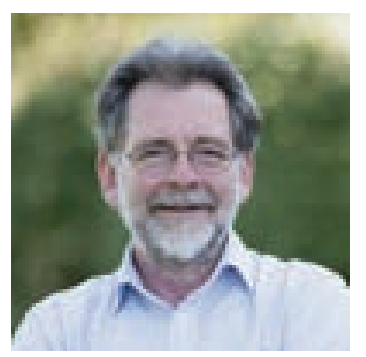

Course

Convenor:

Professor

Hugh White

Asia is in the throes of a major powerpolitical revolution, as a radical change in the distribution of wealth and power overtakes the old order and forces the creation of a new one. Explore three areas of the new power politics of Asia: the nature of power politics as a mode of international relations; the power politics of Asia today, what is happening and where it is going; and concepts that can help us better understand power politics.

\section{STST8010 Strategic Studies Concepts and Methods}

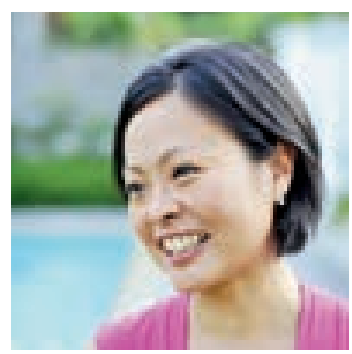

Course

Convenor:

Professor

Evelyn Goh

Explore inter-disciplinary concepts, theories and methods that inform Strategic Studies academic research. Using the overarching empirical theme of the Cold War, investigate three areas: understanding critical developments during the Cold War; historiographical and methodological debates in the study of the Cold War; and theoretical and conceptual methods employed by scholars in the most influential works in Strategic Studies.
STST8027 Insurgency \& Counterinsurgency in an Age of Terror

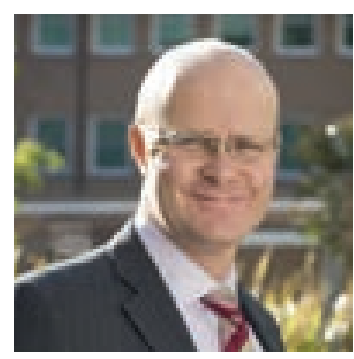

Course Convenor: Dr Garth Pratten

To understand contemporary insurgencies in places such such as Iraq and Afghanistan this course establishes a strong historical framework by examining earlier conflicts from North America to Southeast and South Asia. It encourages students to evaluate contemporary counter-insurgency practice, including those campaigns being waged as part of the attempt to defeat transnational terrorism, against the backdrop of the evolution of counterinsurgency strategies.

Other courses you can study in your degree include: Strategic Studies; The Resort to Force: Understanding Military Power; Australian Strategic and Defence Policy; Great and Powerful Friends: Strategic Alliances and Australian Security; Strategic Studies Internship; Special Topics in Strategic Studies; Intelligence and Security; Nuclear Strategy in the Asian Century; China's Defence and Strategic Challenges; Why and How We Fight: Understanding War and Conflict; Contemporary Issues in Australian Defence Policy.

For more information visit: programsandcourses.anu.edu.au

Coral Bell School of Asia Pacific Affairs ANU College of Asia \& the Pacific

\section{Contact}

T 0261257017

E sdsc@anu.edu.au

W sdsc.bellschool.anu.edu.au 